\title{
Recent advances in ocular drug delivery systems and targeting VEGF receptors for management of ocular angiogenesis: A comprehensive review
}

\author{
Soumya Narayana ${ }^{1}$, Mohammed Gulzar Ahmed ${ }^{1 *}$, B. H. Jaswanth Gowda', Pallavi K. Shetty ${ }^{1}$, Arfa Nasrine ${ }^{1}$,
} M. Thriveni ${ }^{1}$, Nadira Noushida ${ }^{2}$ and A. Sanjana ${ }^{1}$

\begin{abstract}
Background: Angiogenic ocular diseases address the main source of vision impairment or irreversible vision loss. The angiogenesis process depends on the balance between the pro-angiogenic and anti-angiogenic factors. An imbalance between these factors leads to pathological conditions in the body. The vascular endothelial growth factor is the main cause of pathological conditions in the ocular region. Intravitreal injections of anti-angiogenic drugs are selective, safe, specific and revolutionized treatment for ocular angiogenesis. But intravitreal injections are invasive techniques with other severe complications. The area of targeting vascular endothelial growth factor receptors progresses with novel approaches and therapeutically based hope for best clinical outcomes for patients through the developments in anti-angiogenic therapy.
\end{abstract}

Main text: The present review article gathers prior knowledge about the vascular endothelial growth factor and associated receptors with other angiogenic and anti-angiogenic factors involved in ocular angiogenesis. A focus on the brief mechanism of vascular endothelial growth factor inhibitors in the treatment of ocular angiogenesis is elaborated. The review also covers various recent novel approaches available for ocular drug delivery by comprising a substantial amount of research works. Besides this, we have also discussed in detail the adoption of nanotechnologybased drug delivery systems in ocular angiogenesis by comprising literature having recent advancements. The clinical applications of nanotechnology in terms of ocular drug delivery, risk analysis and future perspectives relating to the treatment approaches for ocular angiogenesis have also been presented.

Conclusion: The novel ocular drug delivery systems involving nanotechnologies are of great importance in the ophthalmological sector to overcome traditional treatments with many drawbacks. This article gives a detailed insight into the various approaches that are currently available to be a road map for future research in the field of ocular angiogenesis disease management.

Keywords: Ocular drug delivery, Ocular angiogenesis, Nanotechnology, Vascular endothelial growth factor, Photothermal therapy

*Correspondence: mohammedgulzar1@gmail.com

1 Department of Pharmaceutics, Yenepoya Pharmacy College and Research Centre, Yenepoya (Deemed to be University),

Mangalore 575018, India

Full list of author information is available at the end of the article

\section{Background}

Visual impairment has become a major threat to all age category people globally. According to the reports, almost 246 million people are affected by subnormal vision, 285 million people with vision disabilities and 39 
million people with blindness $[1,2]$. In India, more than 30 percent of people become blind before they cross 17 years of age and most of them are of less than 5 years [3]. Impairment in vision is also widespread among elderly individuals in various other forms [4]. According to a study conducted in Al-Madinah Al-Munawarah, Saudi Arabia, among diabetic patients $(n=690), 36.1 \%$ were found to be suffering from diabetic retinopathy (DR) of which $6.4 \%$ had proliferative disease [5]. An additional cross-sectional study conducted in Al Ain, United Arab Emirates reported DR in 19\% of diabetic patients $(n=513)$. Almost all the patients were completely unaware of the condition of their retina [6, 7]. Approximately $8.7 \%$ of worldwide blindness is occurred due to age-related macular degeneration (AMD) especially in aged patients [8]. Angiogenesis accounts for the formation of new blood vessels from the existing vasculature. The physiological angiogenesis process in the human body is the balance between anti-angiogenic and proangiogenic factors [9]. Disturbance of such balance leads to a pathological condition in the human body. During the conditions such as wound healing and peripheral arterial disease ischemic heart disease, the stimulation of angiogenesis will cure the disease. Wherein case of diseases such as rheumatoid arthritis, cancer and ophthalmic conditions, the inhibition of angiogenesis is the cure [10]. Global ocular morbidity is the main reason behind severe ocular angiogenesis. In ocular angiogenesis conditions, the angiogenic switch must be turned "on" for neovascularization progression [11]. It may lead to diseases like retinal vein occlusions, diabetic retinopathy, corneal neovascularization, age-related macular degeneration, retinopathy of prematurity, choroidal and retinal neovascularization, etc. Pro-angiogenic growth factors implicated in the development of pathological vessels in ocular diseases include endothelial growth factor (EGF), fibroblast growth factor (FGF), platelet-derived growth factor (PDGF), vascular endothelial growth factor (VEGF), etc. [12]. The present review gives clear-cut knowledge on VEGF and their respective receptors with various regulations, affecting factors and available treatments with recent literature. It majorly focuses on numerous novel nanotechnology-based approaches in ocular drug delivery to treat many ocular conditions specifically angiogenesis to overcome traditional injection treatments that affect bioavailability and patient compliance.

\section{Main text}

\section{Regulation of angiogenesis}

In the human body, angiogenesis is involved in various processes [13]. In healthy adults, angiogenesis is a rare phenomenon, involved only locally and transiently under distinctive physiological and pathological conditions in the body. Angiogenesis is regulated by endogenous proangiogenic and anti-angiogenic factors (Table 1) [12, 14-16]. Among all angiogenic and anti-angiogenic factors, VEGF is marked to be a highly critical regulator of ocular angiogenesis. Regulation of angiogenesis involved five steps, initially, angiogenic factors bind to endothelial cells leading to the degradation of basement membrane with the proliferation of endothelial cell, further, migration and also tube formation, elongation finally vessel stabilization (Fig. 1).

\section{Vascular endothelial growth factor (VEGF)}

VEGF is a signal protein also known as vascular permeability factor. The VEGF family includes various members, i.e., VEGF-A, VEGF-B, VEGF-C, VEGF-D, placenta growth factor (PGF) and the viral VEGF homologue VEGF-E. VEGFs bind selectively with receptors namely VEGF receptor-1 (VEGFR-1), VEGFR-2, VEGFR-3, neuropilin-1 (NRP-1) and NRP-2 [34].

\section{VEGF-A}

VEGF-A is one of the well characterized and highly investigated of the VEGF family members. Mainly it enhances the endothelium's permeability by forming the intercellular gaps and fenestrations. Hence, it was originally known as a vascular permeability factor (VPF). Most commonly VEGF-A isoforms have been identified from six transcripts: $\mathrm{VEGF}_{111}, \mathrm{VEGF}_{121}, \mathrm{VEGF}_{145}, \mathrm{VEGF}_{165}, \mathrm{VEGF}_{189}$ and $\mathrm{VEGF}_{206}[19]$.

\section{VEGF-B}

VEGF-B is mainly present in various tissues of the body, as well as the retina but it is greatly available in the region of skeletal and heart muscle. VEGF-B also contains two isoforms, VEGF- $B_{167}$ and VEGF- $B_{186}$ by alternative splicing, which signal through VEGFR-1 and NRP-1. Genetic studies showed the absence of VEGF-B in experimental mice is healthy, fertile and not affected with any vascular diseases. This concludes that VEGF-B is not responsible for angiogenesis [20].

\section{PGF}

It is expressed mainly in the region of the lungs, placenta and heart that further binds to the VEGFR-1 and NRP-1. The complex formation between VEGFR-1 and VEGFR-2 is due to the attachment of PGF to VEGFR-1 that in turn leads to the signaling of VEGF-A and stimulation of angiogenesis $[19,35]$.

\section{VEGF-C, VEGF-D and Viral VEGF homologue VEGF-E}

Both VEGF-C and VEGF-D bind to VEGFR-2 and with lower affinity, it binds to VEGFR-3. It also stimulates the proliferation of endothelial cells and also migration both 
Table 1 Pro-angiogenic and anti-angiogenic factors involved in the angiogenesis process

\begin{tabular}{|c|c|c|c|c|}
\hline Factor & Type & Function & Properties & References \\
\hline VEGF & Angiogenic & Stimulator of angiogenesis & $\begin{array}{l}\text { Produced in the eye by retinal pigment epithe- } \\
\text { lial cells } \\
\text { Upregulated by hypoxic condition } \\
\text { Contains } 5 \text { ligands \{VEGF-A, B, C, D and placental } \\
\text { growth factor (PGF)\} } \\
\text { Consists of three protein-tyrosine kinases } \\
\text { \{(VEGFR-1, Flt-1), (VEGFR-2, Flk-1/KDR), (VEGFR- } \\
\text { 3)\} } \\
\text { Two non-protein kinase co-receptors: neuropi- } \\
\text { lin-1 and neuropilin-2 }\end{array}$ & [17-20] \\
\hline EGF \& TGF & Angiogenic & $\begin{array}{l}\text { Associated with signaling pathway in cancer } \\
\& \text { enhances cell proliferation process, leads to } \\
\text { metastasis besides decreased apoptosis }\end{array}$ & $\begin{array}{l}\text { Binds to VEGF receptors } \\
\text { Mitogens for endothelial cells in vitro, in vivo }\end{array}$ & {$[21,22]$} \\
\hline Angiopoietins & Angiogenic & $\begin{array}{l}\text { Promotes angiogenesis in the uterus or embry- } \\
\text { onic vascular development }\end{array}$ & $\begin{array}{l}\text { Paracrine growth factor } \\
\text { Contains } 4 \text { ligands Angiopoietin 1, 2, 3, } 4 \text { (Ang-1, } \\
2,3,4 \text { ) } \\
\text { Two corresponding tyrosine-kinase receptors } \\
\text { (Tie-1 and Tie-2) }\end{array}$ & [23-25] \\
\hline FGF & Angiogenic & Stimulates angiogenesis & $\begin{array}{l}\text { FGF contains mainly FGF-1 and FGF-2 and it is } \\
\text { also called acidic and basic FGF } \\
\text { FGF-1 (acidic FGF) and FGF-2 (basic FGF) }\end{array}$ & [26] \\
\hline MMP & Angiogenic & Degradation of the basement membrane & $\begin{array}{l}\text { Belongs to the category of soluble and mem- } \\
\text { brane tied proteolytic enzymes }\end{array}$ & [27] \\
\hline PEDF & Anti-angiogenic & Promotes endothelial cell apoptosis & $\begin{array}{l}\text { Also known as serpin F1 } \\
\text { Secreted by retinal epithelial cells } \\
\text { First factor is described for its neurotrophic } \\
\text { properties in vitro }\end{array}$ & {$[28,29]$} \\
\hline Prolactin & Anti-angiogenic & $\begin{array}{l}\text { Suppresses cell proliferation process also } \\
\text { stimulates expression of plasminogen activator } \\
\text { inhibitor }\end{array}$ & $\begin{array}{l}\text { N-terminal } 16-k D a \text { fragment } \\
16 \text { K-PRL is a natural inhibitor of ocular angio- } \\
\text { genesis }\end{array}$ & {$[30,31]$} \\
\hline Angiostatin & Anti-angiogenic & $\begin{array}{l}\text { Inhibits ATP synthesis and that slows down } \\
\text { migration of EC and proliferation }\end{array}$ & $\begin{array}{l}\text { It is a fragment of protein plasminogen } \\
\text { Plasminogen and angiostatin can be synthesized } \\
\text { by corneal layers }\end{array}$ & [19] \\
\hline Vaso inhibins & Anti-angiogenic & $\begin{array}{l}\text { It blocks inducers of angiogenesis (VEGF, FGF, } \\
\text { etc.) through in vitro and in vivo }\end{array}$ & It can be generated by various proteases (MMP's) & {$[32]$} \\
\hline Endostatin & Anti-angiogenic & $\begin{array}{l}\text { Suppresses migration and proliferation of } \\
\text { endothelial cells and increases apoptosis }\end{array}$ & Derived from collagen XVIII & [19] \\
\hline Thrombospondin & Anti-angiogenic & Assists in tumor death & $\begin{array}{l}\text { First discovered in activated platelets } \\
\text { Contains five multifunctional proteins that can } \\
\text { bind extracellular calcium that is TSP-1 to TSP-5 }\end{array}$ & [33] \\
\hline
\end{tabular}

VEGF vascular endothelial growth factor, $P G F$ placental growth factor, $K D R$ kinase-insert-domain receptor, $E G F$ epidermal growth factor, TGF transforming growth factor, FGF fibroblast growth factor, MMP matrix metalloproteinase, $P E D F$ pigment epithelium-derived factor, EC endothelial cells

in vitro and in vivo. VEGF-E is also a potent angiogenic. The binding of VEGF-E to VEGFR-2 with greater affinity results in angiogenesis stimulation and vascular permeability thus increasing in viral infection $[20,36]$.

\section{VEGF receptors}

VEGFs bind selectively with receptors namely VEGF receptor-1 (VEGFR-1), also called Flt-1; VEGFR-2, also called Flk-1; VEGFR-3, also called Flt-4; neuropilin-1 (NRP-1), and NRP-2. The VEGFRs belong to the family of the tyrosine-kinase receptor. The receptor dimerization is caused due to the binding of the ligand to an extracellular immunoglobulin-like domain. The angiogenic effect of VEGF-A was mediated by a vital receptor called VEGFR-2 [19].

\section{VEGFR-1}

Vascular endothelial growth factor receptor-1 (VEGFR-1) is also termed as fms-like tyrosine kinase-1 (Flt-1) which is having $180 \mathrm{kDa}$ and is also seemingly linked to receptor tyrosine kinase (RTK). The VEGFR-2 and Flt-1 are majorly expressed on vascular endothelium, Even though some of the mRNA remains in the stroma of human placenta, monocytes and renal mesangial cells. With high affinity, VEGF- $A_{165}$ binds to VEGFR1 when compared with VEGF-A $\mathrm{A}_{121}[37,38]$. 


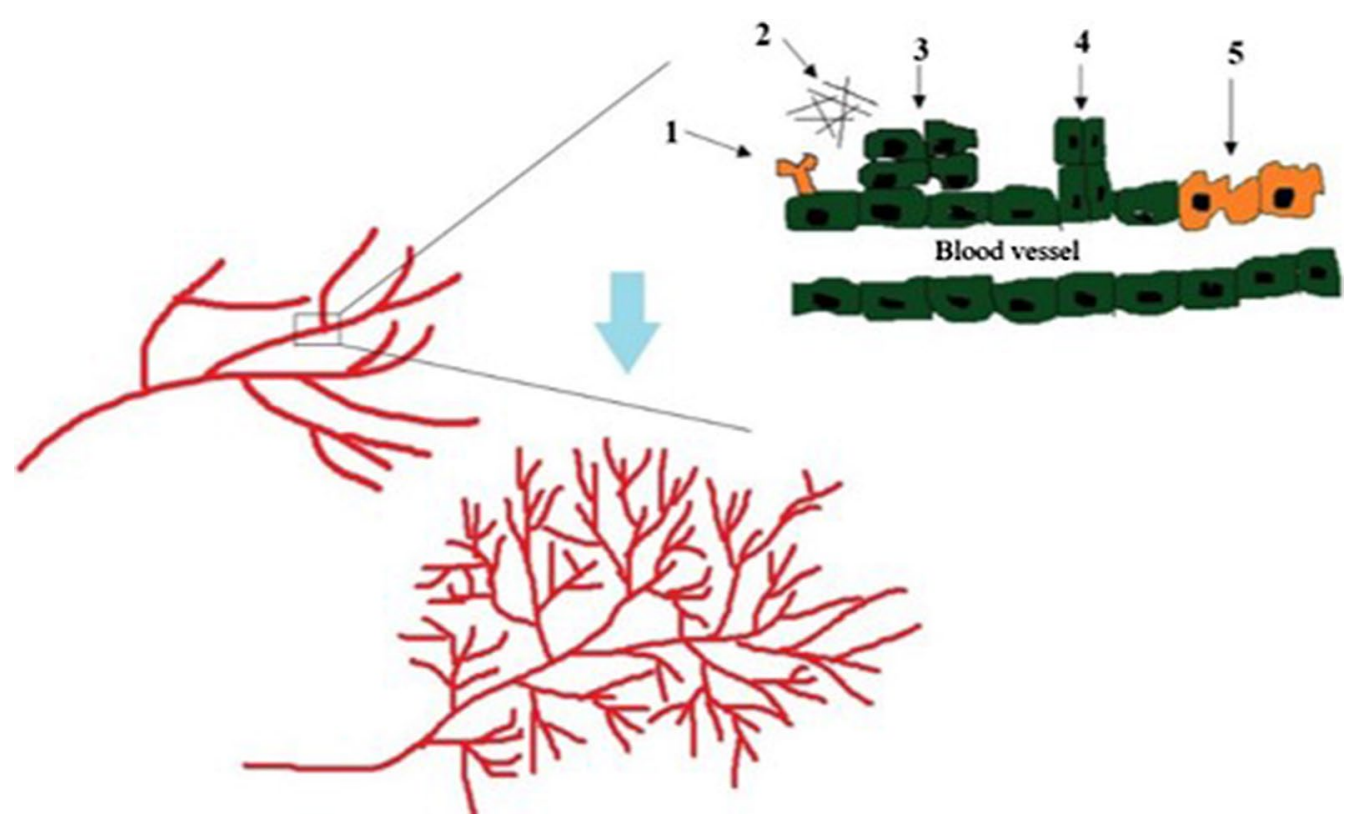

Fig. 1 Regulation of angiogenesis (Steps: 1. Angiogenic factors bind to endothelial cells, 2. Basement membrane degradation, 3. Endothelial cell proliferation and migration, 4. Tube formation, elongation and remodeling and 5. Vessel stabilization.) [13]

\section{VEGFR-2}

VEGFR-2 is the second VEGF tyrosine-kinase receptor that is present on chromosome $4 \mathrm{q} 12$. It is also called a kinase-insert-domain containing receptor (KDR). This KDR is majorly expressed in the region where endothelial cells are abundantly present and were also replicated from a human endothelial cell cDNA library. Due to the ligands of VEGF family, the VEGFR-1 and VEGFR-2 convert the signals for endothelial cells [39].

\section{VEGFR-3}

VEGFR-3 is also called fms insert-like tyrosine kinase 4 (Flt-4). They have got the extracellular domain which is almost $80 \%$ homologue to the other VEGFRs. The VEGF-C and VEGF-D that belong to the family of VEGF are also associated with VEGFR-3. The Flt-4 is majorly expressed in lymphatic endothelium specifically in adult tissues which are usually not seen for VEGFR-1 and VEGFR-2 [40].

\section{Neuropilins}

The neuropilin-1 (NRP-1) and neuropilin-2 (NRP-2) are expressed in endothelial cells just like VEGFR-1 and VEGFR-2. It is particularly with less affinity binds to the VEGF-A 165 . The neuropilin-1 balances the development of blood vessels during the angiogenesis embryonic stage, conveying a major role for VEGFR-2 as a coreceptor [41].

\section{Regulation of VEGF}

VEGF is a crucial regulator of angiogenesis, in a condition of uncontrolled regulation of VEGF leads to pathological angiogenesis. As we have already discussed earlier, angiogenesis is a balance between the pro-angiogenic and anti-angiogenic factors if is there any imbalance between these factors that leads to pathological angiogenesis [42]. Although, many growth factors and cytokines are released in response to any damage in the tissue which leads to stimulation of angiogenesis either directly or indirectly through VEGF that is crucial in tissue repairing. The elevated pathological angiogenesis is occurred due to the stimulation of VEGF expression during pathophysiological conditions like diabetes mellitus and cancer. The literature data was supported this hypothesis by demonstrating suppression of neovascularization by the inhibition of VEGF or its effects. But, during the conditions like atherosclerosis, the elevated concentration of plasma VEGF might be an attempt to make up for the damage of tissue $[43,44]$. In all these pathological conditions, angiogenesis is stimulated by local tissue hypoxia. The ocular cells like muller cells, astrocytes, retinal pigmented epithelium, endothelial cells (EC) and ganglion cells secret and produce VEGF. In vitro studies showed 
that under hypoxic condition muller cells and astrocytes produces larger amounts of VEGF [45].

\section{Effect of oxygen, nitric oxide, glucose and other growth factors on VEGF regulation}

In various diseases like atherosclerosis, solid tumors, ocular diseases, etc., the stimulation of VEGF results in neovascularization and it is mainly due to the hypoxic condition. The major protein named hypoxia-inducible protein complex (HIPC) or hypoxia-inducible factor (HIF) is produced by hypoxia. The up-regulation of transcription of VEGF mRNA was occurred due to the activation of basic heteromeric helix-loop-helix transcriptional regulator. The production and stability of some VEGF isoforms are majorly due to the hypoxia condition. In terms of stability, the VEGF-A isoforms are highly sensitive to hypoxia, wherein the case of VEGF-B and VEGF-C mRNA has little or no effect on hypoxia [46, 47]. The vascular endothelium and endothelial cells can release nitric oxide (NO) in response to VEGF. Additionally, during the VEGF-induced angiogenesis, the production of nitric oxide synthase (NOS) is also increased. A demonstration showed the part of NO in VEGF-induced angiogenesis on NOS knock-out mice as well as after inhibition of NOS, leads to angiogenesis depletion [48, 49]. In the beginning, the increased expression of VEGF was believed to be from the hypoxic condition but it was the hypoglycemic condition. However, in later stages, it was reported that the cells exposed to hypoglycemia without HIF (hypoxia) elevated the expression and upregulation of VEGF. The production of VEGF came back to the pre-experimental level in response to a balanced concentration of glucose suggesting the acute hypoglycemia is the sole responsible to activate angiogenesis mediated via VEGF. Also, pro-angiogenic growth factors such as fibroblast growth factor 4 (FGF 4), tumor necrosis factor- $\alpha$ (TNF- $\alpha$ ), transforming growth factor- $\beta$ (TGF$\beta)$, insulin-like growth factor I, PDGF, angiotensin-2, keratinocyte growth factor, interleukin 1 (IL-1) and IL-6 can alter the production of VEGF. It was also found that some of the anti-angiogenic growth factors such as the cytokines IL-10 and IL-13 can deduce the production of VEGF $[50,51]$.

\section{Angiogenesis inhibitors or vascular endothelial growth factor inhibitors (anti-VEGF)}

The inhibition of VEGF-VEGFRs protein factors unlocked new prospects in medicine since they are the sole ones responsible for many pathological conditions such as angiogenesis and ocular vascular diseases. In many ocular neovascularization conditions, the hindrance of VEGF activity plays a major role in treating such conditions. In recent years, research to develop anti-VEGF has transformed the treatment of ocular angiogenic conditions. These are the most considered treatments for many conditions such as vein occlusions, myopic neovascularization of the choroid, retinopathy of prematurity (ROP), diabetic macular edema and choroidal neovascularization [52, 53]. The FDA approved the ranibizumab for many treatments such as macular edema along with branch retinal vein occlusion (BRVO) and also for treating all angiographic subtypes of the subfoveal neovascularization of AMD [54, 55]. Many literatures indicated short-term effects of ranibizumab on foveal thickness (FT) and visual acuity for about 1 week and 1 month, respectively, after injecting the ranibizumab. The short-term effects ranging from few minutes to hours, after injection of anti-VEGF drugs for BRVO have also been evaluated [56]. Bevacizumab is a full-length humanized recombinant monoclonal Immunoglobulin-G (IgG) anti-VEGF-A antibody [57] that is approved to treat many tumors by hindering all the VEGF-A isoforms. Since this therapy is economical compared to other treatments, it is the most widely used anti-VEGF medicine in ophthalmology $[58,59]$. Intravitreous bevacizumab, ranibizumab and aflibercept were potent and also safe in the treatment of diabetic macular edema that causes vision impairment. The mild loss of initial visual acuity was able to manage with help of all three agents with a slight difference between each other. Where, in case of severe loss of initial visual acuity, aflibercept played a better role in improving the vision [60]. In India, a high alert puts ophthalmologists in a legal and ethical dilemma. Commercial entities must not be allowed to dictate which drug should be used for which disorder. The safety of the patient must be the paramount concern and physicians and governmental agencies must ensure this by fair drug compounding practices. Strong leadership of national and international ophthalmological societies is needed to represent the scientific facts regarding bevacizumab to drug regulatory agencies globally [61]. The research initiatives continue at organizations and pharmaceutical companies globally to find a safe and effective medicine for AMD. The currently available anti-VEGF drugs in the market furnish a slight hope but the drawbacks associated with them are such as repeated intravitreal injections that lead to patient incompliance [62]. Many patients living in developing countries like India face an economic crisis due to these expensive treatments. Even though the bevacizumab is not officially approved to treat a wide range of ocular conditions, it has shown better results at a relatively low cost. Since extensive research is still going on. Thus, we may expect the many novel and potent drugs that can treat many ocular neovascular diseases (Table 2) $[63,64]$. 
Table 2 Classification and application of anti-VEGF drugs

\begin{tabular}{|c|c|c|c|c|c|}
\hline Class & Drug name & Mechanism of action & FDA approval & Application & References \\
\hline Monoclonal antibody & Bevacizumab & $\begin{array}{l}\text { Binds to circulating VEGF, thereby } \\
\text { inhibiting binding to its cell surface } \\
\text { receptors thus limits blood supply to } \\
\text { tumor tissue }\end{array}$ & 2004 & $\begin{array}{l}\text { Off label use in ophthalmology } \\
\text { Colorectal cancer } \\
\text { Non-squamous \& non-small cell lung } \\
\text { cancer }\end{array}$ & {$[65,66]$} \\
\hline Antibody derivative & Ranibizumab & $\begin{array}{l}\text { Binds to receptor binding site on } \\
\text { VEGF-A \& blocks all isoforms of } \\
\text { VEGF-A }\end{array}$ & 2006 & $\begin{array}{l}\text { Age-related macular degeneration } \\
\text { Macular edema } \\
\text { Diabetic retinopathy }\end{array}$ & {$[67]$} \\
\hline Aptamer & Pegaptanib & $\begin{array}{l}\text { Binds to extracellular VEGF }{ }_{165} \text { thereby } \\
\text { inhibits binding to the VEGF receptor }\end{array}$ & 2004 & Age-related macular degeneration & {$[68]$} \\
\hline \multirow[t]{3}{*}{$\begin{array}{l}\text { Oral small molecule } \\
\text { (Inhibit tyrosine } \\
\text { kinases) }\end{array}$} & Lapatinib & $\begin{array}{l}\text { Inhibits intracellular tyrosine kinase } \\
\text { domains of epidermal and human } \\
\text { epidermal growth receptors }\end{array}$ & 2007 & Certain type of breast cancer & {$[69,70]$} \\
\hline & Sunitinib & $\begin{array}{l}\text { Inhibits multiple receptor tyrosine } \\
\text { kinase and also PDGFR and VEGFRs }\end{array}$ & 2006 & $\begin{array}{l}\text { Certain types of cancer (kidney, } \\
\text { pancreas and intestinal) }\end{array}$ & {$[71]$} \\
\hline & Sorafenib & $\begin{array}{l}\text { Interacts with multiple cell surface } \\
\text { and multiple intracellular kinases. } \\
\text { Therefore, inhibits transcription }\end{array}$ & 2005 & $\begin{array}{l}\text { Used to treat kidney, liver and thy- } \\
\text { roid cancers }\end{array}$ & {$[72,73]$} \\
\hline Fusion proteins & Aflibercept & $\begin{array}{l}\text { It functions as a decoy receptor for } \\
\text { ligands }\end{array}$ & 2011 & $\begin{array}{l}\text { Age-related macular degeneration } \\
\text { Diabetic retinopathy }\end{array}$ & {$[74]$} \\
\hline \multirow[t]{2}{*}{ Miscellaneous } & siRNA-Bevasiranib & $\begin{array}{l}\text { It is a small interfering RNA (siRNA) } \\
\text { drug that works by silencing the } \\
\text { specific genes that induce VEGF }\end{array}$ & - & $\begin{array}{l}\text { Age-related macular degeneration } \\
\text { Diabetic retinopathy }\end{array}$ & {$[75]$} \\
\hline & adPEDF & $\begin{array}{l}\text { Rapidly increases intraocular levels } \\
\text { ofadPEDF protein in the eye and } \\
\text { hinders unusual development of } \\
\text { blood vessel }\end{array}$ & - & $\begin{array}{l}\text { In the treatment of macular degen- } \\
\text { eration }\end{array}$ & {$[76,77]$} \\
\hline
\end{tabular}

\section{Novel approaches in ocular drug delivery}

The novel approach-based dosage forms in ophthalmic delivery may ray of hope for better therapies for the future, in the treatment of ocular angiogenesis (Table 3).

\section{Ocular gene therapy}

Gene therapy is a novel technique in the field of medicine which delivers the nucleic acids into the cells of a patient as the drug to treat diseases. It is the supplementation of an ineffective gene with a healthy working gene in defective target cells. Depending on the types of cells treated, the gene therapy can be divided into two types called germline and somatic gene therapy. Some of the techniques to achieve gene therapy are said to be inhibition gene therapy, gene augmentation therapy and scavenging specific cells. Ocular gene therapy is the introduction of an exogenous gene product into a host's cell. The delivery of drugs to the ocular region is a hurdle due to the presence of many cellular barriers. These techniques can clear all the hurdles and challenges. To target a tissue, further development in this field with novel strategies may necessary $[78,79]$.

\section{Ocularinserts}

Ocular inserts are tiny, thin, sterile, stratified solid pieces of a device placed into the conjunctival sac to deliver various drugs. Erodible and non-erodible are two types of ocular inserts. Ocular inserts also offer the advantages of increasing the contact time, better bioavailability of drugs and reducing the dosing frequency. Drug release profile from the ocular inserts depends on the following mechanism: diffusion, osmosis and bio-erosion. Within $24 \mathrm{~h}$, the inserts can dissolve completely. The erosion of the inserts is majorly dependent on the type and concentration of polymer used. The pattern of drug release from the ocular inserts varies between individuals depending upon their physiological conditions. The non-erodible inserts consist of either matrix structure or reservoir that helps in sustaining the drug release $[80,81]$.

\section{Ocular implants}

Ocular implant is an artificial material that is surgically implanted in the position of the eye, to improve impaired vision. For the delivery of drugs into a posterior region, the implants are surgically inserted anteriorly to the retinal region and posteriorly to the lens. There are two types of ocular implants biodegradable and non-biodegradable. 


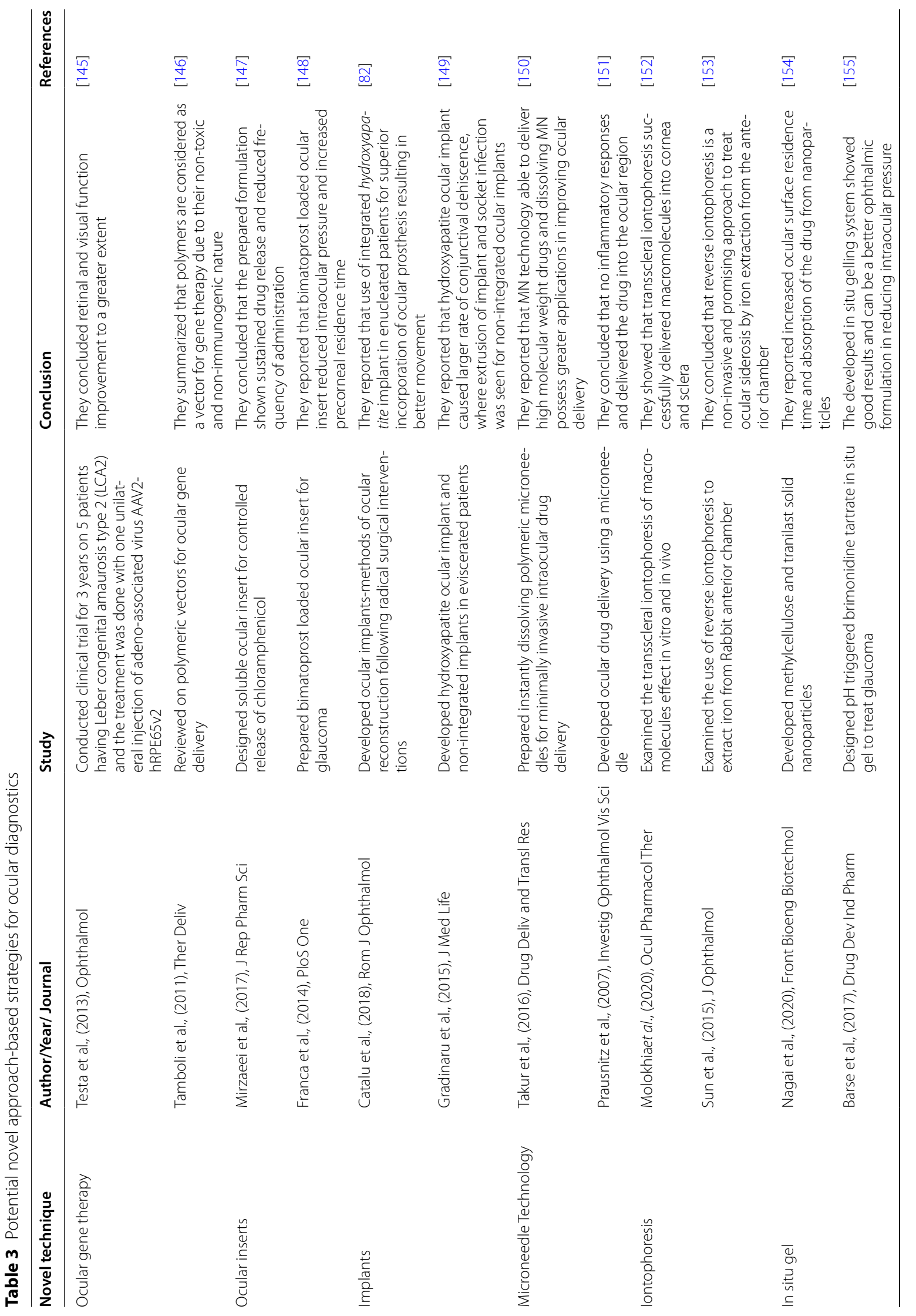




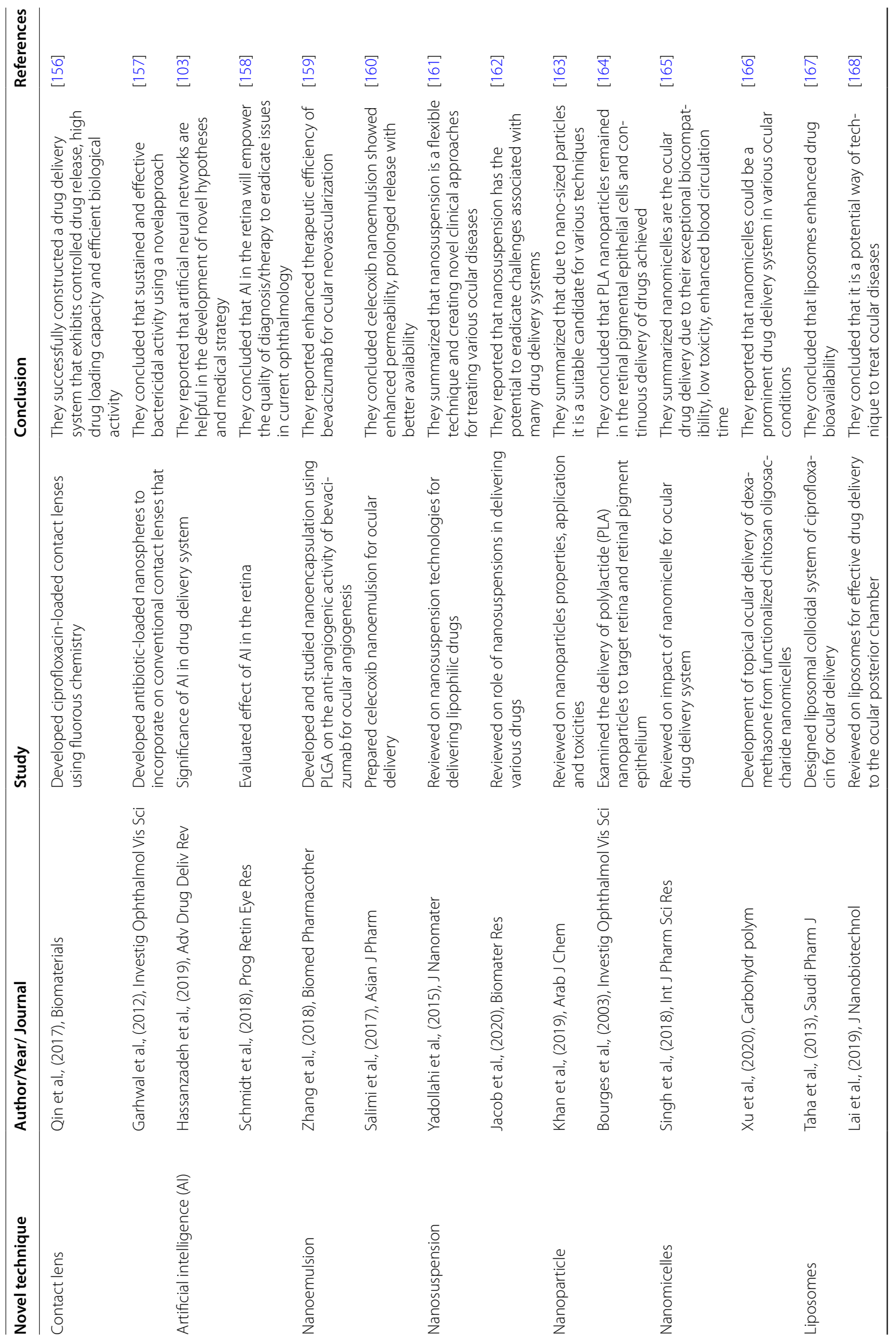




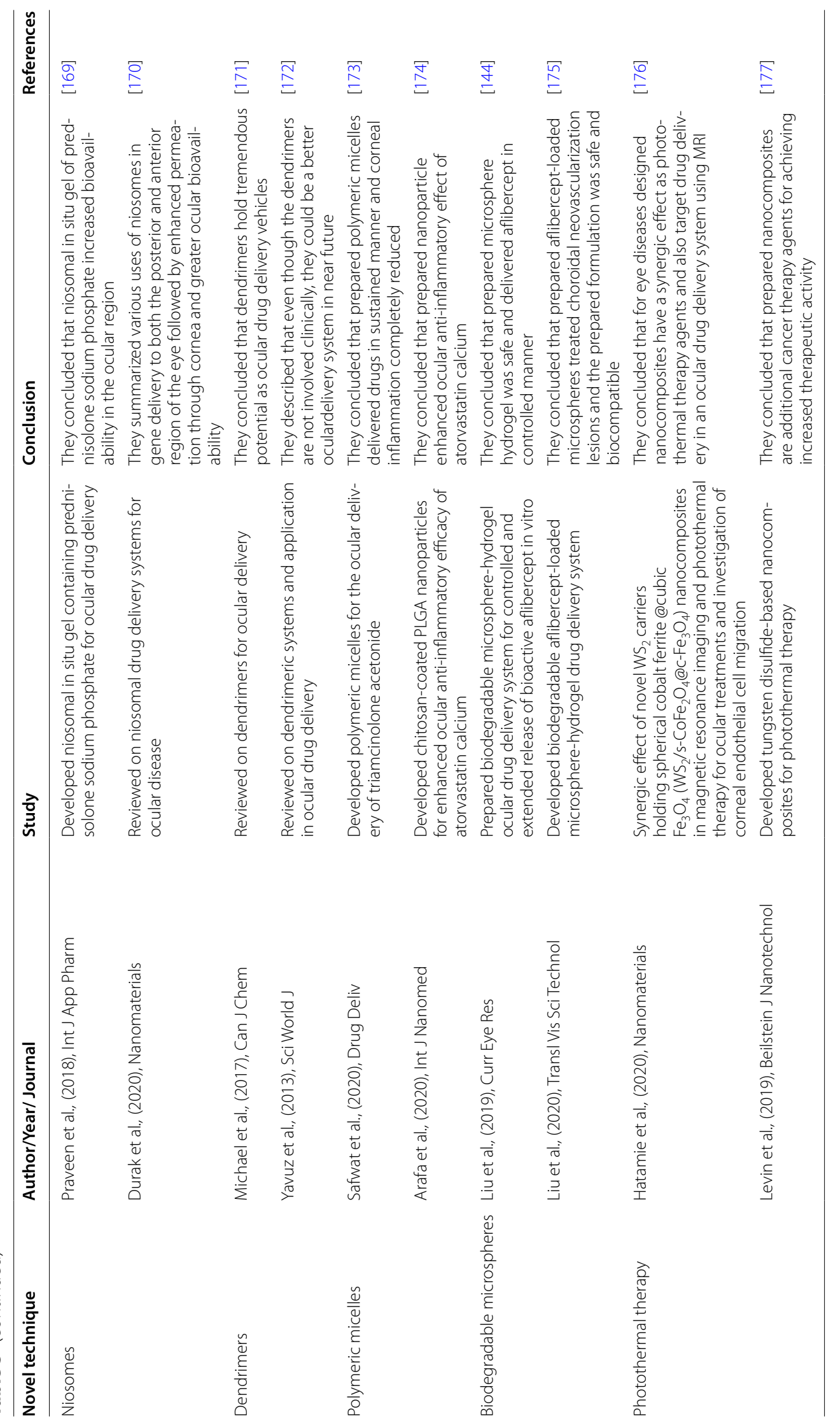


Drugs are encapsulated by using biodegradable polymers like polylactic acid (PLA) and polylactic-co-glycolic acid (PLGA) are in a particular system of nanoparticles or microparticles. The polymers are usually viscous materials that help in releasing the drug for a prolonged period. But, the nanoparticles or microparticles can distribute unusually in the ocular conditions upon injection via needles due to their compact size and composition [82].

\section{Microneedle technology}

These are micron-sized needle configurations, designed using microelectronics industry devices. Besides, microneedles were designed for the delivery of drugs for transdermal delivery. Glass microneedles are made of borosilicate material. Generally, the microneedles were made by using stainless steel called solid microneedles (75-1000 $\mu \mathrm{m}$ in length). It is a minimally invasive technology where it can deliver the drug into the posterior region and also overcomes complications associated with intraocular injections. Mainly, microneedle technology in ophthalmic delivery can provide localized and target delivery of drug into the posterior region [83, 84].

\section{Iontophoresis}

This is a novel technique to deliver various drugs to the target site of action. The drugs, specifically charged macromolecules can be delivered into the anterior and posterior segments. The delivery is mainly based on a basic principle of attraction/binding between opposite charges whereas repelling between same charges. The iontophoretic device consists of a continuous DC source with two electrodes. The mechanism of this device is placing of an ionized drug in the compartment of an electrode that bears the same charge and the ground electrode is placed at any region around the eye [85].

\section{In situ gelling system}

In situ gel is a novel approach to deliver the drug to the ocular region that is solution form before administration and converts into gel form to release the drug that is triggered by an external stimulus like $\mathrm{pH}$, temperature, etc. [86]. Several mechanisms are involved in triggering the conversion of the solution to in situ gel such as a physical change in biomaterials such as exchange of solvent and cross-linking between solvent/swelling. Trigger due to physiological stimuli such as $\mathrm{pH}$ of body fluids and temperature of the body and chemical reactions. Trigger due to various chemical reactions such as photopolymerization, oxidation and reduction. In a temperature triggered system, when the temperature rises, the formulation converts into gel. The polymers like poloxamers are used to formulate these gels. In $\mathrm{pH}$ triggered in situ gel formation of gel is induced by a change in $\mathrm{pH}$. Most of the anionic $\mathrm{pH}$-sensitive polymers are based on polyacrylic acid (PAA) (carbopol, carbomer) or its derivatives. In the diffusion method, the solvent present in the solution of polymer will diffuse and enter the nearby tissue leading to the polymer precipitation. The ionic strength can also promote the formation of gel from the introduced polymeric solution. Gelrite is the best example of an ionsensitive polymer. In the enzyme responsive process, gel formation can be occurred due to specific enzymes present in physiological conditions even in the absence of any chemicals like monomers and initiators. In photopolymerization process, the polymeric solution injected to the desired site will swell with help of a photo via fiber optic cables to sustain the drug release for a longer period $[87,88]$.

\section{Contact lens}

Contact lenses are a thin type of plastic-shaped twisted type of cover that protects the eye. The contact lens can deliver the drug efficiently when compared with eye drops. Due to the longer contact time, the dosage frequency can be lowered with less systematic toxicity. The topical drug delivery to the ocular region became a major hurdle for scientists due to the various barriers like corneal barriers, conjunctival barriers, blood-retinal barriers and blood-aqueous barriers. The fabrication of polymeric nanoparticle embedded contact lens may prolong the delivery of drug leading to reduced frequency of administration which will improve patient compliance [89, 90].

\section{Photothermal therapy}

Photothermal therapy (PTT) is a novel treatment of choice for various medical complications; it is a minimally invasive, local treatment with less toxicity [91]. The mechanism involves the activation of a photosensitizing agent by using electromagnetic radiation to convert energy into heat to kill cancerous cells [92]. PTT has several advantages when compared with radiotherapy or chemotherapy; it specifically targets the unhealthy cell by its deep penetrating power without affecting surrounded healthy cells or tissues [93]. In photothermal therapy, cell death occurs due to the denaturation of proteins, lysis of membrane and evaporation of cytosol [94]. The ideal photosensitizing agent should have several characteristics like low toxicity to the cells, high solubility in biocompatible solution and ease in functionalization. Phosphorous photothermal agents exist in three allotropic forms, i.e., white phosphorous, red phosphorous and black phosphorous (BP) [95]. Among three allotropes of phosphorus, BP is the most stable at high temperature and high pressure. The most interesting properties of BP are its photothermal property, narrow band gaps, large specific surface 
area, high carrier mobility, good biodegradability and biocompatibility properties [96]. Studies have been shown that BP offers promising and better applications in the nano-field of technologies like bio-imaging, photothermal therapy and drug delivery fields. BP is a direct bandgap semiconductor in which band topology remains the same and also it has high carrier mobility [97]. Bulk silicon is another photothermal agent that has an indirect bandgap semiconductor, which means its valence band maximum and conduction band minimum have different momentum vectors. The photoluminescence effect of BP increases exponentially as the layer thickness decreases from 5 to 2 layers [97, 98]. In silicon nanocrystals, the wavelength of photoluminescence is dependent on the diameter of nanocrystals. The photothermal effect is mainly the conversion of optical energy to thermal energy. In ocular phototherapy, the laser is the source of light [99]. Ocular phototherapy has wide application in the treatment of ocular tumors [100]. The study has been conducted to assess the safety and clinical efficacy of non-damaging photothermal therapy for the treatment of the retina. The study included 16 patients suffering from persistent central serous retinopathy who were treated with the PASCAL streamline at $577 \mathrm{~nm}$ wavelength, using $200 \mathrm{~mm}$ retinal spot sizes. They concluded that photothermal therapy was safe and it was improved visual acuity and resolution of subretinal fluid in patients suffering from chronic central serous retinopathy [101]. Another study was conducted to evaluate the effect of near-infrared (NIR) on photothermal therapy agents by using Ag@Oxides nanoprisms for uveal melanoma therapy. Silver oxide nanoparticles were prepared by a simple sol-gel route and irradiated with an $808 \mathrm{~nm}$ NIR laser. They concluded that Ag@oxides nanoparticles were demonstrated to be an efficient photothermal therapy agent for solid cancers by local delivery [102].

\section{Artificial intelligence}

For the last two decades, pharmaceutical scientists are developing novel techniques for targeted drug delivery with maximum efficacy by minimizing the side effects. Artificial intelligence (AI) is the branch of computer science also and it is the intelligence demonstrated by machines. Generation of new information, automated working system and prediction, continuous performance, monitoring various diseases is the main advantage of AI. AI technique enables prediction of pharmacokinetic responses including quantitative structural activity relationships, in vivo responses, etc. So, the incorporation of AI technology into the ophthalmic sector may be a ray of hope for the ocular drug delivery system [103].

\section{Nanotechnology in ophthalmic drug delivery}

Many researchers are facing huge problems in the sector of ocular drug delivery. The bioavailability of a drug is not up to the mark due to several ocular barriers [104, 105]. Many literatures revealed that the particle size of the drug should be appropriate and narrow. It should also possess less irritation, more biocompatible and possess appropriate bioavailability to achieve ocular drug delivery [106]. Hence, the ideal ocular drug delivery system must be in the form of eye drops without inducing any irritation or blurred vision [107]. The topical delivery is the only efficient way to deliver the drug into the anterior segment of an eye but the only minute concentration of the drug will reach into the posterior segment of the eye. But the systemic administration will help to achieve a small quantity of drug in the target site of ocular tissues. However, the dose needed to obtain therapeutic efficacy may induce several drug-related side effects. Thus, the adoption of nanotechnology-based drug delivery such as liposomes, niosomes, solid lipid nanoparticles, nanosuspensions, nanoemulsions, nanomicelles and biodegradable microspheres could help in overcoming various toxicity and bioavailability issues of many drugs. The drugs that are intended to deliver to a specific target site for treating many ocular conditions could be achieved by surpassing the ocular barriers. These nanotechnologybased drug delivery systems can also help in sustaining the release of drugs by crossing several ocular barriers such as the blood-retinal barrier in the eye [108]. This can further improve the bioavailability of many drugs thereby increasing the therapeutic efficacy [109].

\section{Nanoemulsions}

They are fine dispersions of infinitesimal droplets of two immiscible liquids. They contain the dispersed phase, where the particles dispersed are in the nanoor submicron range. Generally, the nanoemulsions are made of one or more surfactants containing both hydrophilic and hydrophobic parts. The high-pressure homogenization is adapted to obtain the dispersed globules in a size range of below $100 \mathrm{~nm}$ with a translucent look. Since the nanoemulsions are globule-sized, the dispersions are thermodynamically unstable which requires more surfactants to stabilize. This can be the major reason behind the stickiness of the formulation. The phospholipids are one class, which is also commonly used in stabilizing the nanoemulsion formulation. The four major types of nanoemulsions are $\mathrm{o} / \mathrm{w}$, w/o, w/o/w, o/w/o type emulsion [110-112]. 


\section{Nanosuspension}

They usually consist of hydrophobic drugs that are suspended in the specific dispersion medium. The nanosuspensions can also be prepared using various polymers and resins to sustain the drug release and to achieve therapeutic efficacy by increasing bioavailability [113]. The polymers that are inert and biocompatible without causing any irritation to the iris, cornea, conjunctiva, etc. will be most suitable for ocular drug delivery. The various formulation techniques such as high-pressure homogenization, milling, emulsificationsolvent, precipitation, supercritical fluid process, melt emulsification method, lipid emulsion/microemulsion template and solvent evaporation are used to design the nanoformulation [114].

\section{Nanoparticles}

They are defined as nano-sized particles, whose diameter ranges from 10 to $1000 \mathrm{~nm}$. They are usually made using several types of biodegradable and biocompatible polymers, resins, phospholipids, etc., either occurred naturally (albumin, sodium alginate, chitosan, guar gum, xanthan gum, gelatine, etc.) or synthesized in the laboratory [polycyanoacrylate, poly(D,L-lactides), polylactides, etc.]. These can be used for delivering the drug to ocular tissues efficiently. The nanoparticles consist of three major properties such as larger surface area, highly mobile in the dispersed state and can exhibit what is known as quantum effects. Based on dimension nanoparticles can be classified as one-, two- and threedimensional nanoparticles. The various techniques like emulsion solvent evaporation, double emulsion solvent evaporation, salting out, emulsions-diffusion method and solvent displacement/precipitation method are used to design the nanoparticles $[115,116]$.

\section{Nanomicelles}

The nanomicelles are nano-sized (10-1000 nm), micellarshaped, self-assembling and highly mobile colloidal-like dispersions consisting of a hydrophilic shell and hydrophobic core. They are made of lipids by arranging themselves in a circular form in the solution. The amphiphilic characteristic of fatty acids is responsible for forming a micellar structure since they contain both hydrophilic (polar) and hydrophobic (non-polar) sections. The core of the nanomicelles consists of hydrophilic chains that extend outward, leading to the formation of the clear formulation. Nanomicelles are classified as polymeric nanomicelles, surfactant nanomicelles and polyion complex nanomicelle. The main advantages of nanomicelles are can be prepared easily and finally yields very small size particles which lead to a larger surface area with higher absorption automatically increases the bioavailability of drugs also encapsulates a large number of drugs [117].

\section{Liposomes}

They are spherical vesicles containing a minimum of one hydrophobic (Lipid) bilayer. They are made of many nontoxic lipids and cholesterols such as phosphatidylcholine, phosphatidylethanolamine as far as they are compatible with each other. The liposome vesicles size under 10 to $100 \mathrm{~nm}$ can be named unilamellar vesicles and huge measured vesicles 100 to $300 \mathrm{~nm}$. Liposomes are promising systems for drug delivery due to their size, amphiphilic properties and biocompatibility. The properties of the liposomes significantly vary upon their size, surface charge, preparing method and composition of lipid/cholesterol. Since they possess a specific surface charge, they can be used in delivering various drugs into the ocular tissues. For example, the negative charge bearing corneal surface can attract the positive surface charged liposomes [118].

\section{Niosomes}

The structure of niosomes is quite similar to liposomes except for the composition that is present in liposomes. They are mainly constituted of non-ionic surfactants. They tend to incorporate both hydrophobic and hydrophilic drugs. Unlike liposomes, they are chemically stable and less toxic due to the absence of phospholipids. This makes niosomes select over liposomes in drug delivery. They also exhibit flexibility in structural characterization due to their size, composition and fluidity. This can increase the sustained action of drugs with better bioavailability. The preparation and storage are quite simple in the case of liposomes compared to niosomes due to their composition of non-ionic surfactants over phospholipids [119, 120].

\section{Dendrimers}

They are one more novel drug delivery system for the ocular region. They are the macromolecular compounds composed of symmetric branches surrounding a central core (like a tree). These are the nano-sized polymeric system. The hydrophilic and lipophilic drugs in the central core and are entrapped with polymers. The drug can be either encapsulated inside the dendrimers or bonded to the surface functional groups to achieve drug loading. The preparation and functionalization of dendrimers are easy up to the generation 2 (G2) level, beyond that it will be difficult to fabricate since they are in the nano-size range. But, most of the drugs can be incorporated into the dendrimers of G2 level. Thus, it could be an efficient way to deliver drugs to the ocular region [121]. 


\section{Polymeric micelles}

Polymeric micelles are the novel drug delivery system used to target the drug into the specific site and release it in a controlled manner [122]. Polymeric micelles can be defined as nano-sized molecules of core-shell structure that are formed by the self-association of amphiphilic block copolymers when they are added to an aqueous solvent. Usually, polymeric micelles are spherical in shape and size in the range of $10-100 \mathrm{~nm}$. These are widely used in drug delivery systems due to their low toxicity, nano-size, good biocompatibility and mainly high stability [123]. The release of drug from polymeric micelles depends on (i) physicochemical properties of the drug and copolymer (ii) method of preparation (iii) structure of micelle forming copolymer and drug (iv) localization of drug in the micelle [124]. The methods like drug dissolution, dialysis, oil in water emulsion, solvent evaporation, co-solvent evaporation and freeze-drying are commonly used to encapsulate the drug into micelles [125]. Due to their small size, it is easily penetrated through the ocular tissues and automatically increases the bioavailability of the drugs. The unique core-shell structure of polymeric micelles, hydrophobic drugs can incorporate within the micelle core will lead to increase the aqueous drug solubility $[126,127]$.

\section{Biodegradable microspheres}

Microspheres are spherical microparticles with a size range between 1 and $1000 \mu \mathrm{m}$ [128]. Biodegradable microspheres were prepared by using synthetic and natural biodegradable polymers [129]. Microspheres are mainly of two types, matrix and capsular. The microspheres were fabricated by using biodegradable natural and synthetic polymers [130]. Natural origin biodegradable polymers are sub-classified as polysaccharides and proteins. Polysaccharides are mainly derived from a plant (dextran, starch, pectin), animal (hyaluronic acid), microbial (xanthan, pullulan, alginic acid) and marine source (chitosan) [131]. Proteins are mainly from plant (gluten) animal (gelatin, collagen and albumin) and microbial (polyhydroxyalkanoates) origin. Synthetic biodegradable polymers are classified as polyesters [PLA, polylacticco-glycolic acid (PLGA), polyglycolic acid (PGA), polycaprolactone (PCL) and polyphenylene ether (PPE)], polyorthoesters and polyanhydrides [132]. Diffusion, dissolution and surface erosion are the major mechanism by which drug release from biodegradable microspheres [133]. The biodegradable microspheres prepared by using various techniques like interfacial polymerization [134], in situ polymerization [135], phase separation [136], ionotropic gelation [137], emulsion solvent evaporation [138], double emulsion [139], spray drying [140, 141], spray congealing and air suspension method [142]. In ocular drug delivery, biodegradable microsphere concept has been used to deliver the drug in a controlled manner and to the specific site. Biodegradable microspheres for the intravitreal delivery of acyclovir were formulated and characterized for various characteristics. These microspheres were prepared by spray drying technique which showed good encapsulation efficiency and in vitro dissolution mainly dependent on the molecular weight of the polymer. Also in vivo evaluation evidenced that prepared formulation shown sustained release of acyclovir [143]. A study has been carried out for the controlled and extended release of bioactive aflibercept hydrogel for the treatment of ocular neovascular diseases and studied in vitro release of the drug. They fabricated afliberceptloaded microspheres by using biodegradable synthetic polymers and concluded that the prepared microsphere hydrogel was safe and delivers aflibercept in a controlled and extended manner for the period of 6 months [144].

\section{Advantages of nanotechnology-based anti-angiogenic therapy}

Angiogenesis inhibitors are the revolutionized drug molecules to target existing tumor infiltrating blood vessels and to inhibit the formation of new blood vessels [178]. These agents mainly act on vascular endothelial growth factors and thereby inhibit the angiogenesis process. Currently, intravitreal injections are the treatment of choice but it is associated with several complications [179]. So, here alternative therapy for the treatment of pathological angiogenesis is the nanotechnology-based drug delivery to overcome several complications. Nanoapproach-based drug delivery techniques play an important role to overcome the drawbacks of present therapy due to their interesting physicochemical properties like nano-sized particles, prolonged half-life, high targeting efficiency, high surface area and the small size of the particle may cross ocular barriers [180]. The study has been conducted for the topical delivery of anti-VEGF drugs for the treatment of choroidal neovascularization using cell penetrating peptides. They evaluated the biological efficacy of the topical anti-VEGF using cell penetrating peptide that is compared with the intravitreal anti-VEGF injections. They have shown that cell penetrating peptides have high penetrating capabilities and non-toxic to the eye. In this study, they delivered bevacizumab and ranibizumab to the posterior segment of mouse, rat and pig eyes. They concluded that topical delivery of anti-VEGF with cell penetrating peptide was efficacious as a single intravitreal injection. A study has been highlighted that within $24 \mathrm{~h}$ the cell penetrating peptide and anti-VEGF drug complexes were cleared from the retinal region [181]. Seah et al. reviewed on use of biomaterials for sustained delivery of anti-VEGF to treat retinal 
diseases. They summarized till date nanoformulations, biodegradable implants and hydrogels have emerged as a promising treatment technique. The anti-VEGF drug molecules or biologics are proteins with high molecular weight and these are very sensitive molecules for various environmental conditions. They discussed that biomaterials are the main agent which are involved in the sustained delivery of anti-VEGF drugs to the retina [182]. Selected biomaterials should fulfill several ideal characteristics like it should protect anti-VEGF molecule from degradation by protecting the tertiary and quaternary structure of the protein, should encapsulate a large amount of drugs in minimum volume to avoid intraocular pressure elevation on administration, should capable of sustaining the release of anti-VEGF for a longer period and finally should remain optically clear within the vitreous to avoid blurring of vision [183]. Liu et al. fabricated bevacizumab-loaded PLGA/PCADK (polycyclohexane1,4-diyl acetone dimethylene ketal) microspheres. In vitro bioactivity test was proved through HET CAM assay and biocompatibility was evaluated using New Zealand white rabbits [184]. Sun et al. fabricated bevacizumab-loaded mesoporous silica nanoparticles. Bioactivity test proved through oxygen-induced retinopathy mouse model. Biocompatibility test proved with C57BL/6J mice [185]. Liu et al. fabricated hydrogel technology ranibizumab and aflibercept-loaded PLGA microspheres suspended in a hydrogel. Bioactivity studies proved on laser-induced choroidal neovascularization Long-Evans rat model. These studies showed that novel approach-based topical delivery of anti-VEGF drugs is the choice of a treatment system for pathological angiogenesis $[144,186]$.

\section{Potentials of nanotechnology-based ocular drug delivery systems for clinical applications}

Currently in the pharmaceutical field, ocular drug delivery has become the most challenging area. To overcome this limitation targeted drug delivery system came into existence [187]. Nanotechnology emerged as a promising drug delivery system in the field of ocular therapy. Various nanotechnology-based products have been under investigation and few products have already been clinically approved by the United States Food and Drug Administration (USFDA) and are available for the treatment of medical conditions like autoimmune disorders, cancer, age-related macular degeneration, etc. Currently, many ocular delivery systems are in clinical trials and some products have already been introduced into the market [188]. The development of nanotechnology seems to be a ray of hope for the currently facing challenges. Pre-clinical/clinical/approved formulations (nano/micro) in ocular drug delivery system are listed in Table 4.

\section{Risk analysis}

In the current review, we have presented the applications of novel approaches for the treatment of pathological ocular angiogenesis [209]. The literature survey represented the main aim to formulate these novel approaches and nanotechnology-based formulations to improve the uptake and for the better entrapment efficiency of drug which ultimately improves the therapeutic effect. But, stability was the major problem associated with the nanobased formulations [210]. The reason behind the low therapeutic efficacy of the nanoformulation is their ability to self-aggregate at low drug concentration, affecting the drug entrapment and ultimately leads to poor stability of the formulations. For example, it has been reported that self-aggregation of doxorubicin nanoformulation due to their high ionic strength ultimately leads to the high particle size and affects their drug entrapment efficiency [211]. The same problem was reported for the liposome formulation which increases in size due to their high ionic strength [212]. Another challenge is the swelling mechanism of nanoformulation. When swelling occurs, the size of the particles increases and this limitation can be fixed by controlling the swelling mechanism by using $\mathrm{pH}$-sensitive coatings or the capping agents over the formulation. Finally, certain nanoformulations were failed to meet FDA quality profile and difficulties associated with formulation manufacturing, make nano-approach-based drugs formulation unfit for large-scale production. Thus, the upcoming research should focus on above mentioned challenges and concentrate on large-scale manufacturing of nanoformulations abiding by the guidelines of USFDA to resolve all the associated hurdles and inexpensively $[188,213]$.

\section{Future perspectives}

The vision impairment and irreversible vision loss can be decreased or completely prevented by enormous research and developments necessitate the application of novel approaches and strategies. Novel approaches in the development of ocular dosage forms have very wide applications in the treatment of various ocular diseases. Topical delivery of drugs into the ocular region is one of the best approaches in ocular drug delivery in terms of patient compliance. Despite its seemingly easy way, they possess several limitations such as tear turnover, nasolacrimal drainage, blinking, induced lacrimation that leads to quick elimination of drug particles from the surface of the eye. This results in sub-therapeutic drug levels in the target tissue, particularly at the retinal level. Thus, novel approaches can assist in the manufacture of nano-based formulations. A very less amount of research was carried out on the above 
Table 4 Pre-clinical/clinical/approved formulations in ocular drug delivery system

\begin{tabular}{|c|c|c|c|c|c|}
\hline Drug name & Product name & Formulations/materials & Condition & $\begin{array}{l}\text { Pre-clinical/clinical/ } \\
\text { approved }\end{array}$ & References \\
\hline Cyclosporin & Restasis & Nanoemulsion & Dry eye & Approved & [189] \\
\hline Difluprednate & Durezol & Nanoemulsion & Eye inflammation & Approved & [189] \\
\hline Bevacizumab & - & PLGA /PCADK microspheres & Ocular angiogenesis & Pre-clinical & [184] \\
\hline Bevacizumab & - & $\begin{array}{l}\text { Mesoporous } \\
\text { silica nanoparticles }\end{array}$ & Ocular angiogenesis & Pre-clinical & [185] \\
\hline Bevacizumab & - & PLGA microspheres & Ocular angiogenesis & Pre-clinical & [189] \\
\hline Bevacizumab & - & Albuminated PLGA nanoparticles & Ocular angiogenesis & Pre-clinical & [190] \\
\hline Bevacizumab & - & Chitosan nanoparticles & Ocular angiogenesis & Pre-clinical & [191] \\
\hline Bevacizumab & - & $\begin{array}{l}\text { PLA nanoparticles in porous PLGA } \\
\text { microparticles }\end{array}$ & Ocular angiogenesis & Pre-clinical & [192] \\
\hline Bevacizumab & - & Multi-vesicular liposomes & Ocular angiogenesis & Pre-clinical & [193] \\
\hline Bevacizumab & - & $\begin{array}{l}\text { Egg } \\
\text { phosphatidylcholine:cholesterol } \\
\text { (liposome) }\end{array}$ & Ocular angiogenesis & Pre-clinical & [194] \\
\hline Bevacizumab & - & $\begin{array}{l}\text { OTX-IVT (anti-VEGF intravitreal } \\
\text { hydrogel implant) }\end{array}$ & Ocular angiogenesis & Pre-clinical & [195] \\
\hline Bevacizumab & - & PLGA-PEG-PLGA hydrogel & Ocular angiogenesis & Pre-clinical & [196] \\
\hline Bevacizumab & - & $\begin{array}{l}\text { Vinyl sulfone functionalized hya- } \\
\text { luronic acid (HV-VS) and thiolated } \\
\text { dextran (Dex-SH) hydrogel }\end{array}$ & Ocular angiogenesis & Pre-clinical & [197] \\
\hline Bevacizumab & - & Silk hydrogel & Ocular angiogenesis & Pre-clinical & [198] \\
\hline Bevacizumab & - & $\begin{array}{l}\text { Poly(ethylene glycol)-poly-(serinol } \\
\text { hexamethylene urethane) (ESHU) } \\
\text { hydrogel }\end{array}$ & Ocular angiogenesis & Pre-clinical & {$[199,200]$} \\
\hline $\begin{array}{l}\text { Ranibizumab \& Afliber- } \\
\text { cept }\end{array}$ & - & $\begin{array}{l}\text { PLGA microspheres suspended in } \\
\text { a PEG-PLLA-DA/NIPAA } \\
\text { hydrogel }\end{array}$ & Ocular angiogenesis & Pre-clinical & {$[144,186,201]$} \\
\hline Ranibizumab & Lucentis & Intravitreal injection & $\begin{array}{l}\text { Myopic choroidal neo- } \\
\text { vascularization/Diabetic } \\
\text { retinopathy }\end{array}$ & Approved & {$[202]$} \\
\hline Ranibizumab & - & $\begin{array}{l}\text { Non-biodegradable implant tech- } \\
\text { nology port delivery system }\end{array}$ & Ocular angiogenesis & Clinical Phase III trials & [203] \\
\hline Ranibizumab & - & Replenish posterior micropump & Ocular angiogenesis & Phase I trials & {$[204]$} \\
\hline Dexamethasone & Ozurdex & Biodegradable implant & $\begin{array}{l}\text { Macular edema, Non- } \\
\text { infectious uveitis }\end{array}$ & Approved & {$[205]$} \\
\hline Triamcinolone acetonide & Trivaris & Nanosuspension & Uveitis & Approved & {$[205]$} \\
\hline Triamcinolone acetonide & Kenalog & Nanosuspension & Macular edema & Approved & [205] \\
\hline Fluocinolone acetonide & Retisert & Non-biodegradable implant & Non-infectious Uveitis & Approved & {$[205]$} \\
\hline Fluocinolone acetonide & Iluvien & Non-biodegradable implant & Diabetic macular edema & Approved & {$[205]$} \\
\hline Triamcinolone acetonide & Triesence & Nanosuspension & Maculae edema & Approved & {$[205]$} \\
\hline Verteporfin & Visudyne & Liposome & AMD & Approved & {$[206]$} \\
\hline Aptamer & Macugen & Polymer nanoparticle & Wet AMD & Approved & [206] \\
\hline TLC399 (ProDex) & - & $\begin{array}{l}\text { Lipid-based } \\
\text { nanoparticle }\end{array}$ & Macular edema & Approved & {$[207]$} \\
\hline Latanoprost & Polat-001 & Liposome & Glaucoma & Approved & [207] \\
\hline $\begin{array}{l}\text { Polyethylene glycol } 400 \text { \& } \\
\text { Propylene glycol }\end{array}$ & Systane & Nanoemulsion & Dry eye & Approved & {$[208]$} \\
\hline
\end{tabular}

discussed approaches for ocular angiogenesis particularly. The application of nanomedicine in the ocular drug delivery area has shown great potential in the pharmaceutical field of research [104]. Nanomedicine also has its potential in improving the pharmacokinetic and pharmacodynamic properties of few therapeutic agents. Many nanoformulations are under the pre-clinical and clinical stage of development for the treatment 
of ocular diseases. Unfortunately, this nanotechnologybased drug delivery has few limitations when it enters the large-scale process. The reason behind the low therapeutic efficacy of the nanoformulation is their ability to self-aggregate at low drug concentration, affecting the drug entrapment and ultimately leads to poor stability of the formulations it again leads to the safety and toxicity issue of the prepared formulation. Also, other factors like size, shape, administration dose can influence toxicity in nanomedicine. So advanced nanofabrication technologies like particle replication in non-wetting templates (PRINT) [214] and the hydrogel template method have been introduced to create ocular nanomedicine. This technology can create uniform nanoparticles and microparticles with controlled shape, size and surface modification at a large scale. Another study conducted using the principle of PRINT technology is AR13503 implant, which was manufactured to provide sustained release of drugs for more than 2 months [214, 215]. Considering the immense amount of past and present research on these techniques, there is potential and a ray of hope for better therapies for the future in the treatment of diseases and is with the eventual goal of stopping ocular angiogenesis. There are several areas to be explored for future research for the benefit of a novel therapy for ocular angiogenesis. Furthermore, the ongoing development of novel therapy or modification to current dosage forms in the context of ocular angiogenesis will be helpful to focus on the new strategy of medication for the treatment of angiogenesis.

\section{Conclusion}

As we discussed earlier, drug delivery to the ocular region became challenging to pharmaceutical scientists. The barriers which are present in the eye hinder ocular bioavailability mainly when the drugs are applied topically. So, novel approach-based drug delivery systems are of great importance in the pharmaceutical technology as well as the ophthalmological sector. Thus, for ocular disease management, the design and development of new techniques are mandatory. Only a few works can be seen specifically for ocular angiogenesis. Currently to treat ocular angiogenesis, intravitreal injections of anti-VEGF drugs are the revolutionized treatment. But, repeated intravitreal injections to the eyes lead to several serious complications. So, novel approach-based drug delivery techniques may be a ray of hope for better therapies for the future in the treatment of ocular angiogenesis. Also, the inclusion of novel techniques may be a road map for future research in the field of ocular angiogenesis disease management.

\section{Abbreviations}

DR: Diabetic retinopathy; AMD: Age-related macular degeneration; EGF: Endothelial growth factor; FGF: Fibroblast growth factor; PDGF: Plateletderived growth factor; PDGFR: Platelet-derived growth factor receptor; VEGF: Vascular endothelial growth factor; VEGFR: Vascular endothelial growth factor receptor; PGF: Placenta growth factor; NRP: Neuropilin; VPF: Vascular permeability factor; RTK: Receptor tyrosine kinase; KDR: Kinase-insert-domain containing receptor; EC: Endothelial cells; HIPC: Hypoxia-inducible protein complex; HIF: Hypoxia-inducible factor; NO: Nitric oxide; NOS: Nitric oxide synthase; TNF: Tumor necrosis factor; TGF: Transforming growth factor; L: Interleukin; ROP: Retinopathy of prematurity; BRVO: Branch retinal vein occlusion; IgG: Immunoglobulin-G; PAA: Polyacrylic acid; Al: Artificial intelligence; G2: Generation 2; MMP: Matrix metalloproteinase; PEDF: Pigment epitheliumderived factor; siRNA: Small interfering ribonucleic acid; mRNA: Messenger ribonucleic acid; DNA: Deoxyribonucleic acid; LCA: Leber congenital amaurosis; MN: Microneedle; PLA: Polylactic acid; PTT: Photothermal therapy; BP: Black phosphorous; NIR: Near-infrared; PLGA: Polylactic-co-glycolic acid; PGA: Polyglycolic acid; PCL: Polycaprolactone; PPE: Polyphenylene ether; PCADK:

Polycyclohexane-1,4-diyl acetone dimethylene ketal; PRINT: Particle replication in non-wetting templates.

\section{Acknowledgements}

The authors are thankful to Yenepoya (Deemed to be University), Mangalore, for providing necessary facilities such as access to library, journals and internet sources for writing this article.

\section{Authors' contributions}

SN substantially contributed to the conception and designing of the work and drafted the manuscript. MGA, JGBH and PKS contributed to the writing of the manuscript and substantially revised the whole manuscript. AN, TM, NN and SA contributed in drafting and writing of the manuscript. All authors have read and approved the manuscript.

\section{Funding}

Not applicable.

Availability of data and materials

All data and materials are available on request.

\section{Declarations}

Ethics approval and consent to participate Not applicable.

\section{Consent for publication}

Not applicable.

\section{Competing interests}

The authors declare that they have no conflict of interest.

\section{Author details}

${ }^{1}$ Department of Pharmaceutics, Yenepoya Pharmacy College and Research Centre, Yenepoya (Deemed to be University), Mangalore 575018, India.

${ }^{2}$ Department of Pharmacology, Yenepoya Pharmacy College and Research Centre, Yenepoya (Deemed to be University), Mangalore 575018, India.

Received: 9 February 2021 Accepted: 5 April 2021

Published online: 07 September 2021

\footnotetext{
References

1. Pascolini D, Mariotti SP (2012) Global estimates of visual impairment: 2010. Br J Ophthalmol 96:614-618

2. Rao GN, Sabnam S, Pal S, Rizwan H, Thakur B, Pal A (2018) Prevalence of ocular morbidity among children aged 17 years or younger in the eastern India. Clin Ophthalmol 12:1645-1652
} 
3. Gupta M, Gupta BP, Chauhan A, Bhardwaj A (2009) Ocular morbidity prevalence among school children in Shimla, Himachal, North India. Indian J Ophthalmol 57:133-138

4. Saxena R, Vashist P, Tandon R, Pandey RM, Bhardawaj A, Gupta V, Menon $\checkmark$ (2017) Incidence and progression of myopia and associated factors in urban school children in Delhi: The North India Myopia Study (NIM Study). PLoS One 12:e0189774.

5. ElBab MF, Shawky N, AlSisi A, Akhtar M (2012) Retinopathy and risk factors in diabetic patients from Al-Madinah Al-Munawarah in the Kingdom of Saudi Arabia. Clin Ophthalmol 6:269-276

6. Al-Maskari F, El-Sadig M (2007) Prevalence of diabetic retinopathy in the United Arab Emirates: a cross-sectional survey. BMC ophthalmol 7:11

7. Wong WL, Su X, Li X, Cheung CM, Klein R, Cheng CY, Wong TY (2014) Global prevalence of age-related macular degeneration and disease burden projection for 2020 and 2040: a systematic review and metaanalysis. Lancet Glob Health 2:e106-e116

8. Kawasaki R, Yasuda M, Song SJ, Chen SJ, Jonas JB, Wang JJ, Mitchell P, Wong TY (2010) The prevalence of age-related macular degeneration in Asians: a systematic review and meta-analysis. Ophthalmol 117:921-927

9. Carmeliet P (2000) Mechanisms of angiogenesis and arteriogenesis. Nat Med 6:389-395

10. Risau W (1997) Mechanisms of angiogenesis. Nature 386:671-674

11. Dreyfuss JL, Giordano RJ, Regatieri CV (2015) Ocular angiogenesis. J Ophthalmol 1-3.

12. Cabral T, Mello LGM, Lima LH, Polido J, Regatieri CV, Belfort R Jr, Mahajan VB (2017) Retinal and choroidal angiogenesis: a review of new targets. Int J Retina Vitreous 3:31

13. Yoo SY, Kwon SM (2013) Angiogenesis and its therapeutic opportunities. Mediators Inflamm 1-11.

14. Halin C, Zardi L, Neri D (2001) Antibody-based targeting of angiogenesis. News Physiol Sci 16:191-194

15. Senger DR, Davis GE (2011) Angiogenesis. Cold Spring Harb Perspect Biol 3:1-19

16. Kvanta A (2006) Ocular angiogenesis: the role of growth factors. Acta Ophthalmol Scand 84:282-288

17. Olofsson B, Pajusola K, Kaipainen A, von Euler G, Joukov V, Saksela O, Orpana A, Pettersson RF, Alitalo K, Eriksson U (1996) Vascular endothelial growth factor B, a novel growth factor for endothelial cells. Proc Natl Acad Sci U S A 93:2576-2581

18. Zhou Y, Bellingard V, Feng KT, McMaster M, Fisher SJ (2003) Human cytotrophoblasts promote endothelial survival and vascular remodeling through secretion of Ang2, PIGF, and VEGF-C. Dev Biol 263:1 14-125

19. Distler JH, Hirth A, Kurowska-Stolarska M, Gay RE, Gay S, Distler O (2003) Angiogenic and angiostatic factors in the molecular control of angiogenesis. Q J Nucl Med 47:149-161

20. Veikkola T, Karkkainen M, Claesson-Welsh L, Alitalo K (2000) Regulation of angiogenesis via vascular endothelial growth factor receptors. Cancer Res 60:203-212

21. Baselga I (2002) Why the epidermal growth factor receptor? The rationale for cancer therapy. Oncologist 7:2-8

22. Risau W (1990) Angiogenic growth factors. Prog Growth Factor Res 2:71-79

23. Davis $S$, Aldrich $T H$, Jones $P F$, Acheson $A$, Compton DL, Jain $V$, Ryan $T E$, Bruno J, Radziejewski C, Maisonpierre PC, Yancopoulos GD (1996) Isolation of angiopoietin-1, a ligand for the TIE2 receptor, by secretion-trap expression cloning. Cell 87:1161-1169

24. Maisonpierre PC, Suri C, Jones PF, Bartunkova S, Wiegand SJ, Radziejewski C, Compton D, McClain J, Aldrich TH, Papadopoulos N, Daly TJ, Davis S, Sato TN, Yancopoulos GD (1997) Angiopoietin-2, a natural antagonist for Tie2 that disrupts in vivo angiogenesis. Science 277:55-60

25. Lobov IB, Brooks PC, Lang RA (2002) Angiopoietin-2 displays VEGFdependent modulation of capillary structure and endothelial cell survival in vivo. Proc Natl Acad Sci U S A 99:11205-11210

26. Miller DL, Ortega S, Bashayan O, Basch R, Basilico C (2000) Compensation by fibroblast growth factor 1 (FGF1) does not account for the mild phenotypic defects observed in FGF2 null mice. Mol Cell Biol 20:2260-2268

27. Rundhaug JE(2005) Matrix metalloproteinases and angiogenesis. J Cell Mol Med 9:267-285.
28. Dawson DW, Volpert OV, Gillis P, Crawford SE, Xu H, Benedict W, Bouck NP (1999) Pigment epithelium-derived factor: a potent inhibitor of angiogenesis. Science 285:245-248

29. Holekamp NM, Bouck N, Volpert O (2002) Pigment epithelium-derived factor is deficient in the vitreous of patients with choroidal neovascularization due to age-related macular degeneration. Am J Ophthalmol 134:220-227

30. Aranda J, Rivera JC, Jeziorski MC, Riesgo-Escovar J, Nava G, LópezBarrera F, Quiróz-Mercado H, Berger P, Martínez de la Escalera G, Clapp C (2005) Prolactins are natural inhibitors of angiogenesis in the retina. Invest Ophthalmol Vis Sci 46:2947-2953

31. Ben-Jonathan N, Mershon JL, Allen DL, Steinmetz RW (1996) Extrapituitary prolactin: distribution, regulation, functions, and clinical aspects. Endocr Rev 17:639-669

32. Triebel J, Bertsch T, Bollheimer C, Rios-Barrera D, Pearce CF, Hüfner M, Martínez de la Escalera G, Clapp C (2015) Principles of the prolactin/vasoinhibin axis. Am J Physiol Regul Integr Comp Physiol 309:R1193-R1203

33. Lawler J (2000) The functions of thrombospondin-1 and-2. Curr Opin Cell Biol 12:634-640

34. Tammela T, Enholm B, Alitalo K, Paavonen K (2005) The biology of vascular endothelial growth factors. Cardiovasc Res 65:550-563

35. Holmes DI, Zachary I (2005) The vascular endothelial growth factor (VEGF) family: angiogenic factors in health and disease. Genome Biol 6:209

36. Savory LJ, Stacker SA, Fleming SB, Niven BE, Mercer AA (2000) Viral vascular endothelial growth factor plays a critical role in orf virus infection. J Virol 74:10699-10706

37. Shibuya M, Yamaguchi S, Yamane A, Ikeda T, Tojo A, Matsushime H, Sato M (1990) Nucleotide sequence and expression of a novel human receptor-type tyrosine kinase gene (flt) closely related to the fms family. Oncogene 5:519-524

38. Rosnet O, Matteï MG, Marchetto S, Birnbaum D (1991) Isolation and chromosomal localization of a novel FMS-like tyrosine kinase gene. Genomics 9:380-385

39. Katoh O, Tauchi H, Kawaishi K, Kimura A, Satow Y (1995) Expression of the vascular endothelial growth factor (VEGF) receptor gene, KDR, in hematopoietic cells and inhibitory effect of VEGF on apoptotic cell death caused by ionizing radiation. Cancer Res 55:5687-5692

40. Joukov V, Kaipainen A, Jeltsch M, Pajusola K, Olofsson B, Kumar V, Eriksson U, Alitalo K (1997) Vascular endothelial growth factors VEGF-B and VEGF-C. J Cell Physiol 173:211-215

41. Kitsukawa T, Shimizu M, Sanbo M, Hirata T, Taniguchi M, Bekku Y, Yagi T, Fujisawa H (1997) Neuropilin-semaphorin III/D-mediated chemorepulsive signals play a crucial role in peripheral nerve projection in mice. Neuron 19:995-1005

42. Adamis AP, Shima DT, Tolentino MJ, Gragoudas ES, Ferrara N, Folkman J, D'Amore PA, Miller JW (1996) Inhibition of vascular endothelial growth factor prevents retinal ischemia-associated iris neovascularization in a nonhuman primate. Arch Ophthalmol 114:66-71

43. Aiello LP, Pierce EA, Foley ED, Takagi H, Chen H, Riddle L, Ferrara N, King GL, Smith LE (1995) Suppression of retinal neovascularization in vivo by inhibition of vascular endothelial growth factor (VEGF) using soluble VEGF-receptor chimeric proteins. Proc Natl Acad Sci U S A 92:10457-10461

44. Shweiki D, Neeman M, Itin A, Keshet E (1995) Induction of vascular endothelial growth factor expression by hypoxia and by glucose deficiency in multicell spheroids: implications for tumor angiogenesis. Proc Natl Acad Sci U S A 92:768-772

45. Siemerink MJ, Augustin AJ, Schlingemann RO (2010) Mechanisms of ocular angiogenesis and its molecular mediators. Dev Ophthalmol 46:4-20

46. Forsythe JA, Jiang BH, lyer NV, Agani F, Leung SW, Koos RD, Semenza GL (1996) Activation of vascular endothelial growth factor gene transcription by hypoxia-inducible factor 1. Mol Cell Biol 16:4604-4613

47. Jiang BH, Semenza GL, Bauer C, Marti HH (1996) Hypoxia-inducible factor 1 levels vary exponentially over a physiologically relevant range of O2 tension. Am J Physiol 271:C1172-1180

48. Murohara T, Horowitz JR, Silver M, Tsurumi Y, Chen D, Sullivan A, Isner JM (1998) Vascular endothelial growth factor/vascular permeability 
factor enhances vascular permeability via nitric oxide and prostacyclin. Circulation 97:99-107

49. Miyazaki H, Matsuoka H, Cooke JP, Usui M, Ueda S, Okuda S, Imaizumi $T$ (1999) Endogenous nitric oxide synthase inhibitor: a novel marker of atherosclerosis. Circulation 99:1141-1146

50. Sone H, Kawakami Y, Okuda Y, Kondo S, Hanatani M, Suzuki H, Yamashita K (1996) Vascular endothelial growth factor is induced by long-term high glucose concentration and up-regulated by acute glucose deprivation in cultured bovine retinal pigmented epithelial cells. Biochem Biophys Res Commun 221:193-198

51. Deroanne CF, Hajitou A, Calberg-Bacq CM, Nusgens BV, Lapière CM (1997) Angiogenesis by fibroblast growth factor 4 is mediated through an autocrine up-regulation of vascular endothelial growth factor expression. Cancer Res 57:5590-5597

52. Ciulla TA, Rosenfeld PJ (2009) Anti-vascular endothelial growth factor therapy for neovascular ocular diseases other than age-related macular degeneration. Curr Opin Ophthalmol 20:166-174

53. Tah V, Orlans HO, Hyer J, Casswell E, Din N, Sri Shanmuganathan V, Ramskold L, Pasu S (2015) Anti-VEGF therapy and the retina: an update. J Ophthalmol 2015:627674

54. Zampros I, Praidou A, Brazitikos P, Ekonomidis P, Androudi S (2012) Antivascular endothelial growth factor agents for neovascular age-related macular degeneration. J Ophthalmol 2012:319728

55. Campochiaro PA, Heier JS, Feiner L, Gray S, Saroj N, Rundle AC, Murahashi WY, Rubio RG, Investigators BRAVO (2010) Ranibizumab for macular edema following branch retinal vein occlusion: six-month primary end point results of a phase III study. Ophthalmology 117:1102-1112.e1

56. Popescu V, Pricopie S, Totir M, lancu R, Yasyn S, Alexandrescu C (2015) Clinical use of Bevacizumab in treating refractory glaucoma. J Med Life 8:8-12

57. Park SC, Su D, Tello C (2012) Anti-VEGF therapy for the treatment of glaucoma: a focus on ranibizumab and bevacizumab. Expert OpinBiol Ther 12:1641-1647

58. SooHoo JR, Seibold LK, Kahook MY (2014) The link between intravitreal antivascular endothelial growth factor injections and glaucoma. Curr Opin Ophthalmol 25:127-133

59. Cardarelli WJ, Smith RA (2013) Managed care implications of agerelated ocular conditions. Am J Manag Care 19:85-91

60. Wells JA, Glassman AR, Ayala AR, Jampol LM, Aiello LP, Antoszyk AN, Arnold-Bush B, Baker CW, Bressler NM, Browning DJ, Elman MJ, Ferris FL, Friedman SM, Melia M, Pieramici DJ, Sun JK, Beck RW (2015) Aflibercept, bevacizumab, or ranibizumab for diabetic macular edema. N Engl J Med 372:1193-1203

61. Kumar A, Tripathy K, Chawla R (2017) Intraocular use of bevacizumab in India: an issue resolved? Natl Med I India 30:345-347

62. Azad R, Chandra P, Gupta R (2007) The economic implications of the use of anti-vascular endothelial growth factor drugs in age-related macular degeneration. Indian J Ophthalmol 55:441-443

63. Iturralde D, Spaide RF, Meyerle CB, Klancnik JM, Yannuzzi LA, Fisher YL, Sorenson J, Slakter JS, Freund KB, Cooney M, Fine HF (2006) Intravitreal bevacizumab (Avastin) treatment of macular edema in central retinal vein occlusion: a short-term study. Retina 26:279-284

64. Shah PK, Narendran V, Tawansy KA, Raghuram A, Narendran K (2007) Intravitreal bevacizumab (Avastin) for post laser anterior segment ischemia in aggressive posterior retinopathy of prematurity. Indian. Ophthalmol 55:75-76

65. Shih T, Lindley C (2006) Bevacizumab: an angiogenesis inhibitor for the treatment of solid malignancies. Clin Ther 28:1779-1802

66. Kazazi-Hyseni F, Beijnen JH, Schellens JH (2010) Bevacizumab Oncologist 15:819-825

67. Kim LA, D'Amore PA (2012) A brief history of anti-VEGF for the treatment of ocular angiogenesis. Am J Pathol 181:376-379

68. Ng EW, Shima DT, Calias P, Cunningham ET, Guyer DR, Adamis AP (2006) Pegaptanib, a targeted anti-VEGF aptamer for ocular vascular disease. Nat Rev Drug Discov 5:123-132

69. Nelson MH, Dolder CR (2006) Lapatinib: a novel dual tyrosine kinase inhibitor with activity in solid tumors. Ann Pharmacother 40:261-269

70. Segovia-Mendoza M, González-González ME, Barrera D, Díaz L, GarcíaBecerra R (2015) Efficacy and mechanism of action of the tyrosine kinase inhibitors gefitinib, lapatinib and neratinib in the treatment of
HER2-positive breast cancer: preclinical and clinical evidence. Am J Cancer Res 5:2531-2561

71. Abrams TJ, Lee LB, Murray LJ, Pryer NK, Cherrington JM (2003) SU11248 inhibits KIT and platelet-derived growth factor receptor beta in preclinical models of human small cell lung cancer. Mol Cancer Ther 2:471-478

72. Schöffski P, Dumez H, Clement P, Hoeben A, Prenen H, Wolter P, Joniau S, Roskams T, Van Poppel H (2006) Emerging role of tyrosine kinase inhibitors in the treatment of advanced renal cell cancer: a review. Ann Oncol 17:1185-1196

73. Adnane L, Trail PA, Taylor I, Wilhelm SM (2006) Sorafenib (BAY 43-9006, Nexavar), a dual-action inhibitor that targets RAF/MEK/ERK pathway in tumor cells and tyrosine kinases VEGFR/PDGFR in tumor vasculature. Methods Enzymol 407:597-612

74. Browning DJ, Kaiser PK, Rosenfeld PJ, Stewart MW (2012) Aflibercept for age-related macular degeneration: a game-changer or quiet addition? Am J Ophthalmol 154:222-226

75. Dejneka NS, Wan S, Bond OS, Kornbrust DJ, Reich SJ (2008) Ocular biodistribution of bevasiranib following a single intravitreal injection to rabbit eyes. Mol Vis 14:997-1005

76. Wei L (2005) Adenovector pigment epithelium-derived factor (AdPEDF) delivery for wet age-related macular degeneration. Retina 25:S48-49

77. Rasmussen H, Chu KW, Campochiaro P, Gehlbach PL, Haller JA, Handa JT, Nguyen QD, Sung JU (2001) Clinical protocol: an open-label, phase I, single administration, dose-escalation study of ADGVPEDF.11D (ADPEDF) in neovascular age-related macular degeneration (AMD). Hum Gene Ther 12:2029-2032

78. Olly JK, Bridge H, MacLaren RE (2019) Outcome measures used in ocular gene therapy trials: a scoping review of current practice. Front Pharmacol 10:1076

79. Souto EB, Dias-Ferreira J, López-Machado A, Ettcheto M, Cano A, Camins Espuny A, Espina M, Garcia ML, Sánchez-López E (2019) Advanced formulation approaches for ocular drug delivery: state-of-the-art and recent patents. Pharmaceutics 11:460

80. Kumari A, Sharma PK, Garg VK, Garg G (2010) Ocular inserts: advancement in therapy of eye diseases. J Adv Pharm Technol Res 1:291-296

81. Shende PK, Godbole R (2016) Current and novel techniques in the ophthalmic drug delivery systems. Int J Pharm Sci Res 7:3557-3566

82. Catalu CT, Istrate SL, Voinea LM, Mitulescu C, Popescu V, Radu C (2018) Ocular implants-methods of ocular reconstruction following radical surgical interventions. Rom J Ophthalmol 62:15-23

83. Chao Z, Dong C, Fang H (2017) Current Perspective on microneedles for ocular drug delivery. Saudi J Med Pharm Sci 3:772-776

84. Thakur Singh RR, Tekko I, McAvoy K, McMillan H, Jones D, Donnelly RF (2016) Minimally invasive microneedles for ocular drug delivery. Expert Opin Drug Deliv 14:525-537

85. Zhang Y, Chen Y, Yu X, Qi Y, Chen Y, Liu Y, Hu Y, Li Z (2016) A flexible device for ocular iontophoretic drug delivery. Biomicrofluidics 10:011911

86. Sanajan A, Ahmed MG, Gowda BHJ (2021) Preparation and evaluation of in-situ gels containing hydrocortisone for the treatment of aphthous ulcer. J Oral Biol Craniofac Res 11:269-276

87. Kushwaha SK, Saxena P, Rai AK (2012) Stimuli sensitive hydrogels for ophthalmic drug delivery: a review. Int J Pharm Investig 2:54-60

88. Kouchak M (2014) In situ gelling systems for drug delivery. Jundishapur J Nat Pharm Prod 9:e20126

89. Choi SW, Kim J (2018) Therapeutic contact lenses with polymeric vehicles for ocular drug delivery: a review. Materials (Basel) 11:1125

90. Xu J, Xue Y, Hu G, Lin T, Gou J, Yin T, He H, Zhang Y, Tang X (2018) A comprehensive review on contact lens for ophthalmic drug delivery. J Control Release 281:97-118

91. Fong JF, Ng YH, Ng SM (2018) Carbon dots as a new class of light emitters for biomedical diagnostics and therapeutic applications. In: Grumezescu AM (ed) Fullerens, Graphenes and Nanotubes, William Andrew Publishing

92. Eskiizmir G, Ermertcan AT, Yapici K (2017) Nanomaterials: promising structures for the management of oral cancer. In: Andronescu E, Grumezescu AM (ed) Nanostructures for oral medicine, Elsevier

93. Jaque D, Martínez Maestro L, del Rosal B, Haro-Gonzalez P, Benayas A, Plaza JL, Martín Rodríguez E, García Solé J (2014) Nanoparticles for photothermal therapies. Nanoscale 6:9494-9530 
94. Lapotko D (2009) Therapy with gold nanoparticles and lasers: what really kills the cells? Nanomedicine (Lond) 4:253-256

95. Pandey A, Nikam AN, Fernandes G, Kulkarni S, Padya BS, Prassl R, Das S, Joseph A, Deshmukh PK, Patil PO, Mutalik S (2020) Black phosphorus as multifaceted advanced material nanoplatforms for potential biomedical applications. Nanomaterials (Basel) 11:13

96. Xie Z, Peng M, Lu R, Meng X, Liang W, Li Z, Qiu M, Zhang B, Nie G, Xie N, Zhang H, Prasad PN (2020) Black phosphorus-based photothermal therapy with aCD47-mediated immune checkpoint blockade for enhanced cancer immunotherapy. Light Sci Appl 9:161

97. Qiu M, Singh A, Wang D, Qu J, Swihart M, Zhang H, Prasad PN (2019) Biocompatible and biodegradable inorganic nanostructures for nanomedicine: silicon and black phosphorus. Nano Today 25:135-155

98. Sun Z, Xie H, Tang S, Yu XF, Guo Z, Shao J, Zhang H, Huang H, Wang H, Chu PK (2015) Ultrasmall black phosphorus quantum dots: synthesis and use as photothermal agents. Angew Chem Int Ed Engl 54:11526-11530

99. Liu J, Erogbogbo F, Yong KT, Ye L, Liu J, Hu R, Chen H, Hu Y, Yang Y, Yang J, Roy I, Karker NA, Swihart MT, Prasad PN (2013) Assessing clinical prospects of silicon quantum dots: studies in mice and monkeys. ACS Nano 7:7303-7310

100. Singh AD (2013) Ocular phototherapy Eye 27:190-198

101. Lavinsky D, Palanker D (2015) Nondamaging photothermal therapy for the retina: initial clinical experience with chronic central serous retinopathy. Retina 35:213-222

102. Luo L, Nie C, Du P, Hongwei Z, Wei W, Zhang M, Ambati B, Sun Z (2015) An efficient near-infrared photothermal therapy agent by using Ag@ Oxides nanoprisms in for uveal melanoma therapy. Investig Ophthalmol Vis Sci 56:1540

103. Hassanzadeh P, Atyabi F, Dinarvand R (2019) The significance of artificial intelligence in drug delivery system design. Adv Drug Deliv Rev 151:169-190

104. Sanna V, Pala N, Sechi M (2014) Targeted therapy using nanotechnology: focus on cancer. Int J Nanomedicine 9:467-483

105. Liu S, Jones LW, Gu FX (2016) Nanotechnology and nanomaterials in ophthalmic drug delivery. In: Pathak Y, Sutariya V, Hirani A (eds) Nanobiomaterials for ophthalmic drug delivery. Springer, Cham

106. Behar-Cohen F (2004) Vectorisation intra-oculaire [Drug delivery to target the posterior segment of the eye]. Med Sci 20:701-706

107. Dey S, Mitra AK (2005) Transporters and receptors in ocular drug delivery: opportunities and challenges. Expert Opin Drug Deliv 2:201-204

108. Kokate A, Marasanapalle V, Jasti BR, Li X (2006) Physiological and biochemical barriers to drug delivery. In: Li X, Jasti BR (eds) Design of controlled release drug delivery systems. McGraw-Hill, New York, pp 41-73

109. Yasukawa T, Ogura Y, Tabata Y, Kimura H, Wiedemann P, Honda Y (2004) Drug delivery systems for vitreoretinal diseases. Prog Retin Eye Res 23:253-281

110. Jaiswal M, Dudhe R, Sharma PK (2015) Nanoemulsion: an advanced mode of drug delivery system. 3 Biotech 5:123-127

111. Patel RP, Joshi JR (2012) An overview on nanoemulsion: a novel approach. Int J Pharm Sci Res 3:4640

112. Ammar HO, Salama HA, Ghorab M, Mahmoud AA (2009) Nanoemulsion as a potential ophthalmic delivery system for dorzolamide hydrochloride. AAPSPharmSciTech 10:808

113. Shankar SJ, Gowda JBH, Akshatha RS, Metikurki B, Rehamathulla M (2020) A review on role of nanocrystals and nanosuspensions in drug delivery systems. Int J App Pharm 12:10-16

114. Shid RL, Dhole SN, Kulkarni N, Shid SL (2013) Nanosuspension: a review. Int J Pharm Sci Rev Res 20:98-106

115. Pal SL, Jana U, Manna PK, Mohanta GP, Manavalan R (2011) Nanoparticle: an overview of preparation and characterization. J App Pharm Sci $1: 228-234$

116. Brigger I, Dubernet C, Couvreur P (2012) Nanoparticles in cancer therapy and diagnosis. Adv Drug Deliv Rev 64:24-36

117. Cholkar K, Patel A, Vadlapudi AD, Mitra AK (2012) Novel nanomicella formulation approaches for anterior and posterior segment ocular drug delivery. Recent Pat Nanomed 2:82-95

118. Bhattacharjee A, Das PJ, Adhikari P, Marbaniang D, Pal P, Ray S, Mazumder B (2019) Novel drug delivery systems for ocular therapy:
With special reference to liposomal ocular delivery. Eur J Ophthalmol 29:113-126

119. Sahoo SK, Dilnawaz F, Krishnakumar S (2008) Nanotechnology in ocular drug delivery. Drug Discov Today 13:144-151

120. Guinedi AS, Mortada ND, Mansour S, Hathout RM (2005) Preparation and evaluation of reverse-phase evaporation and multilamellar niosomes as ophthalmic carriers of acetazolamide. Int J Pharm 306:71-82

121. Abbasi E, Aval SF, Akbarzadeh A, Milani M, Nasrabadi HT, Joo SW, Hanifehpour Y, Nejati-Koshki K, Pashaei-AsI R (2014) Dendrimers: synthesis, applications, and properties. Nanoscale Res Lett 9:247

122. Yadav HK, Almokdad AA, Sumia IM, Debe MS (2019) Polymer-based nanomaterials for drug-delivery carriers. In: Mohapatra SS, Ranjan S, Dasgupta N, Mishra RK, Thomas S (ed) Nanocarriers for Drug Delivery, Elsevier

123. Croy SR, Kwon GS (2006) Polymeric micelles for drug delivery. Curr Pharm Des 12:4669-4684

124. Mourya VK, Inamdar N, Nawale RB, Kulthe SS (2011) Polymeric micelles:general consideration and their applications. Indian J Pharm Educ Res 45:128-138

125. Nishiyama N (2019) Polymeric micelles. In: Matsumura, Yasuhiro, Tarin, David (ed) Cancer Drug Delivery Systems Based on the Tumor Microenvironment, Springer, Tokyo.

126. Mandal A, Bisht R, Rupenthal ID, Mitra AK (2017) Polymeric micelles for ocular drug delivery: from structural frameworks to recent preclinical studies. J Control Release 248:96-116

127. Hanafy NAN, El-Kemary M, Leporatti S (2018) Micelles structure development as a strategy to improve smart cancer therapy. Cancers 10:238

128. Milovanovic M, Arsenijevic A, Milovanovic J, Kanjevac T, Arsenijevic N (2017) Nanoparticles in antiviral therapy. In: Grumezescu AM (ed) Antimicrobial nanoarchitectonics, Elsevier.

129. Prajapati VD, Jani GK, Kapadia JR (2015) Current knowledge on biodegradable microspheres in drug delivery. Expert Opin Drug Deliv 12:1283-1299

130. Zhang Y, Chu CC (2002) In vitro release behavior of insulin from biodegradable hybrid hydrogel networks of polysaccharide and synthetic biodegradable polyester. J Biomater Appl 16:305-325

131. Kumara BN, Shambhu R, Prasad KS (2021) Why chitosan could be apt candidate for glaucoma drug delivery: an overview. Int J Biol Macromol 176:47-65

132. Umeki N, Sato T, Harada M, Takeda J, Saito S, Iwao Y, Itai S (2010) Preparation and evaluation of biodegradable microspheres containing a new potent osteogenic compound and new synthetic polymers for sustained release. Int J Pharm 392:42-50

133. Zhang M, Yang Z, Chow LL, Wang CH (2003) Simulation of drug release from biodegradable polymeric microspheres with bulk and surface erosions. J Pharm Sci 92:2040-2056

134. Desai KGH, Park HJ (2005) Recent developments in microencapsulation of food ingredients. Drying Tech 23:1361-1394

135. Brown EN, Kesseler MR, Sottos NR, White SR (2003) In situ poly(urea-formaldehyde) microencapsulation of dicyclopentadiene. J Microencapsul 20:719-730

136. Dubey R, Shami TC, Rao KU (2009) Microencapsulation technology and applications. Def Sci J 59:82-95

137. Patil U, Chaudhari KP, Jadhao UT, Thakare VM, Tekade BW (2014) Formulation and evaluation of Albendazole microspheres by ionotropic gelation method. J Adv Pharm Edu Res 4:114-124

138. Zheng CH, Gao JQ, Zhang YP, Liang WQ (2004) A protein delivery system: biodegradable alginate-chitosan-poly(lactic-co-glycolic acid) composite microspheres. Biochem Biophys Res Commun 323:1321-1327

139. Wang D, Molavi O, Lutsiak ME, Elamanchili P, Kwon GS, Samuel J (2007) Poly(D, L-lactic-co-glycolic acid) microsphere delivery of adenovirus for vaccination. J Pharm Pharm Sci 10:217-230

140. Giunchedi P, Conte U, Chetoni P, Saettone MF (1999) Pectin microspheres as ophthalmic carriers for piroxicam: evaluation in vitro and in vivo in albino rabbits. Eur J Pharm Sci 9:1-7

141. Burke PA, Klumb LA, Herberger JD, Nguyen XC, Harrell RA, Zordich M (2004) Poly(lactide-co-glycolide) microsphere formulations of darbepoetin alfa: spray drying is an alternative to encapsulation by spray-freeze drying. Pharm Res 21:500-506 
142. Fu YJ, Shyu SS, Su FH, Yu PC (2002) Development of biodegradable copoly (D, L-lactic/glycolic acid) microspheres for the controlled release of 5-FU by the spray drying method. Colloids Surf B Biointerfaces 25:269-279

143. Conti B, Bucolo C, Giannavola C, Puglisi G, Giunchedi P, Conte U (1997) Biodegradable microspheres for the intravitreal administration of acyclovir: in vitro/in vivo evaluation. Eur J Pharm Sci 5:287-293

144. Liu W, Lee BS, Mieler WF, Kang-Mieler JJ (2019) Biodegradable microsphere-hydrogel ocular drug delivery system for controlled and extended release of bioactive aflibercept in vitro. Curr Eye Res 44:264-274

145. Testa F, Maguire AM, Rossi S, Pierce EA, Melillo P, Marshall K, Banfi S, Surace EM, Sun J, Acerra C, Wright JF, Wellman J, High KA, Auricchio A, Bennett J, Simonelli F (2013) Three-year follow-up after unilateral subretinal delivery of adeno-associated virus in patients with Leber congenital Amaurosis type 2. Ophthalmology 120:1283-1291

146. Tamboli V, Mishra GP, Mitrat AK (2011) Polymeric vectors for ocular gene delivery. Ther Deliv 2:523-536

147. Mirzaeei S, Alizadeh M (2017) Design and evaluation of soluble ocular insert for controlled release of chloramphenicol. J Rep Pharm Sci 6:123-133

148. Franca JR, Foureaux G, Fuscaldi LL, Ribeiro TG, Rodrigues LB, Bravo R, Castilho RO, Yoshida MI, Cardoso VN, Fernandes SO, Cronemberger S (2014) Bimatoprost-loaded ocular inserts as sustained release drug delivery systems for glaucoma treatment: in vitro and in vivo evaluation. PLOS ONE 9:95461

149. Gradinaru S, Popescu V, Leasu C, Pricopie S, Yasin S, Ciuluvica R, Ungureanu E (2015) Hydroxyapatite ocular implant and non-integrated implants in eviscerated patients. J Med Life 8:90-93

150. Thakur RR, Tekko IA, Al-Shammari F, Ali AA, McCarthy H, Donnelly RF (2016) Rapidly dissolving polymeric microneedles for minimally invasive intraocular drug delivery. Drug Deliv Transl Res 6:800-815

151. Prausnitz MR, Jiang J, Patel SR, Gill HS, Ghate D, McCarey BE, Geroski DH, Edelhauser HF (2007) Ocular drug delivery using microneedles. Investig Ophthalmol Vis Sci 48:3191

152. Molokhia S, Papangkorn K, Butler C, Higuchi JW, Brar B, Ambati B, Li SK, Higuchi WI (2020) Transscleral iontophoresis for noninvasive ocular drug delivery of macromolecules. J Ocul Pharmacol Ther 36:247-256

153. Sun S, Diao H, Zhao F, Bai J, Zhou Y, Cui H, Zhang L (2015) Extraction of iron from the rabbit anterior chamber with reverse iontophoresis. J Ophthalmol 2015:425438.

154. Nagai N, Minami M, Deguchi S, Otake H, Sasaki H, Yamamoto N (2020) An in situ gelling system based on methylcellulose and tranilast solid nanoparticles enhances ocular residence time and drug absorption into the cornea and conjunctiva. Front Bioeng Biotechnol 8:764

155. Barse RK, Tagalpallewar AA, Kokare CR, Sharma JP, Sharma PK (2018) Formulation and ex vivo-in vivo evaluation of $\mathrm{pH}$-triggered brimonidine tartrate in situ gel for the glaucoma treatment using application of 32 factorial design. Drug Dev Ind Pharm 44:800-807

156. Qin G, Zhu Z, Li S, McDermott AM, Cai C (2017) Development of ciprofloxacin-loaded contact lenses using fluorous chemistry. Biomaterials 124:55-64

157. Garhwal R, Shady SF, Ellis EJ, Ellis JY, Leahy CD, McCarthy SP, Crawford KS, Gaines P (2012) Sustained ocular delivery of ciprofloxacin using nanospheres and conventional contact lens materials. Investig Ophthalmol Vis Sci 53:1341-1352

158. Schmidt-Erfurth U, Sadeghipour A, Gerendas BS, Waldstein SM, Bogunović H (2018) Artificial intelligence in retina. Prog Retin Eye Res 67:1-29

159. Zhang XP, Sun JG, Yao J, Shan K, Liu BH, Yao MD, Ge HM, Jiang Q, Zhao C, Yan B (2018) Effect of nanoencapsulation using poly (lactide-coglycolide) (PLGA) on anti-angiogenic activity of bevacizumab for ocular angiogenesis therapy. Biomed Pharmacother 107:1056-1063

160. Salimi A (2017) Preparation and evaluation of celecoxib nanoemulsion for ocular drug delivery. Asian J Pharm 11:543-549

161. Yadollahi R, Vasilev K, Simovic S (2015) Nanosuspension technologies for delivery of poorly soluble drugs. J Nanomater 1:2015

162. Jacob S, Nair AB, Shah J (2020) Emerging role of nanosuspensions in drug delivery systems. Biomater Res 24:3

163. Khan I, Saeed K, Khan I (2019) Nanoparticles: properties, applications and toxicities. Arab J Chem 12:908-931
164. Bourges JL, Gautier SE, Delie F, Bejjani RA, Jeanny JC, Gurny R, BenEzra D, Behar-Cohen FF (2003) Ocular drug delivery targeting the retina and retinal pigment epithelium using polylactide nanoparticles. Investig Ophthalmol Vis Sci 44:3562-3569

165. Singh P, Verma N (2018) A review on impact of nanomicelle for ocular drug delivery system. Int J Pharm Sci Res 9:1397-1404

166. Xu X, Sun L, Zhou L, Cheng Y, Cao F (2020) Functional chitosan oligosaccharide nanomicelles for topical ocular drug delivery of dexamethasone. Carbohydr Polym 227:115356

167. Taha El, El-Anazi MH, El-Bagory IM, Bayomi MA (2014) Design of liposomal colloidal systems for ocular delivery of ciprofloxacin. Saudi Pharm J 22:231-239

168. Lai S, Wei Y, Wu Q, Zhou K, Liu T, Zhang Y, Jiang N, Xiao W, Chen J, Liu Q, Yu Y (2019) Liposomes for effective drug delivery to the ocular posterior chamber. J Nanobiotechnology 17:64

169. Chaudhari PD, Desai US (2019) Formulation and evaluation of niosomal in situ gel of prednisolone sodium phosphate for ocular drug delivery. Int J App Pharm 11:97-116

170. Durak S, Esmaeili Rad M, Alp Yetisgin A, Eda Sutova H, Kutlu O, Cetinel S, Zarrabi A (2020) Niosomal drug delivery systems for ocular diseaserecent advances and future prospects. Nanomaterials 10:1191

171. Lancina MG 3rd, Yang H (2017) Dendrimers for ocular drug delivery. Can J Chem 95:897-902

172. Yavuz B, BozdağPehlivan S, Ünlü N (2013) Dendrimeric systems and their applications in ocular drug delivery. Sci World J 1:2013

173. Safwat MA, Mansour HF, Hussein AK, Abdelwahab S, Soliman GM (2020) Polymeric micelles for the ocular delivery of triamcinolone acetonide: preparation and in vivo evaluation in a rabbit ocular inflammatory model. Drug Deliv 27:1115-1124

174. Arafa MG, Girgis GNS, El-Dahan MS (2020) Chitosan-coated PLGA nanoparticles for enhanced ocular anti-inflammatory efficacy of atorvastatin calcium. Int J Nanomedicine 15:1335-1347

175. Liu W, Tawakol AP, Rudeen KM, Mieler WF, Kang-Mieler JJ (2020) Treatment efficacy and biocompatibility of a biodegradable afliberceptloaded microsphere-hydrogel drug delivery system. TransI Vis Sci Technol 9:13

176. Hatamie S, Shih PJ, Chen BW, Wang I, Young TH, Yao DJ (2020) Synergic effect of novel WS2 carriers holding spherical Cobalt Ferrite @cubic $\mathrm{Fe}_{3} \mathrm{O}_{4}$ (WS2/s-CoFe $\mathrm{O}_{4} @ \mathrm{c}-\mathrm{Fe}_{3} \mathrm{O}_{4}$ ) nanocomposites in magnetic resonance imaging and photothermal therapy for ocular treatments and investigation of corneal endothelial cell migration. Nanomaterials 10:2555

177. Levin T, Sade H, Binyamini RB, Pour M, Nachman I, Lellouche JP (2019) Tungsten disulfide-based nanocomposites for photothermal therapy. Beilstein J Nanotechnol 10:811-822

178. Comunanza V, Bussolino F (2017) Therapy for cancer: strategy of combining anti-angiogenic and target therapies. Front Cell Dev Biol 5:101

179. Sampat KM, Garg SJ (2010) Complications of intravitreal injections. Curr Opin Ophthalmol 21:178-183

180. Yetisgin AA, Cetinel S, Zuvin M, Kosar A, Kutlu O (2020) Therapeutic nanoparticles and their targeted delivery applications. Molecules 25:2193

181. De Cogan F, Hill $\amalg$, Lynch A, Morgan-Warren PJ, Lechner J, Berwick MR, Peacock AFA, Chen M, Scott RAH, Xu H, Logan A (2017) Topical delivery of anti-VEGF drugs to the ocular posterior segment using cell-penetrating peptides. Invest Ophthalmol Vis Sci 58:2578-2590

182. Seah I, Zhao X, Lin Q, Liu Z, Su SZ, Yuen YS, Hunziker W, Lingam G, Loh XJ, Su X (2020) Use of biomaterials for sustained delivery of anti-VEGF to treat retinal diseases. Eye 34:1341-1356

183. Su X, Tan MJ, Li Z, Wong M, Rajamani L, Lingam G, Loh XJ (2015) Recent progress in using biomaterials as vitreous substitutes. Biomacromol 16:3093-3102

184. Liu J, Li S, Li G, Li X, Yu C, Fu Z, Li X, Teng L, Li Y, Sun F (2019) Highly bioactive, bevacizumab-loaded, sustained-release PLGA/PCADK microspheres for intravitreal therapy in ocular diseases. Int J Pharm 563:228-236

185. Sun JG, Jiang Q, Zhang XP, Shan K, Liu BH, Zhao C, Yan B (2019) Mesoporous silica nanoparticles as a delivery system for improving antiangiogenic therapy. Int J Nanomedicine 14:1489-1501

186. Liu W, Borrell MA, Venerus DC, Mieler WF, Kang-Mieler JJ (2019) Characterization of biodegradable microsphere-hydrogel ocular drug delivery 
system for controlled and extended release of ranibizumab. TransI Vis SciTechnol 8:12

187. Morigi V, Tocchio A, Bellavite Pellegrini C, Sakamoto JH, Arnone M, Tasciotti E (2012) Nanotechnology in medicine: from inception to market domination. J Drug Deliv 2012:389485

188. Nijhara R, Balakrishnan K (2006) Bringing nanomedicines to market: regulatory challenges, opportunities, and uncertainties. Nanomedicine 2:127-136

189. Ye Z, Ji YL, Ma X, Wen JG, Wei W, Huang SM (2015) Pharmacokinetics and distributions of bevacizumab by intravitreal injection of bevacizumab-PLGA microspheres in rabbits. Int J Ophthalmol 8:653-658

190. Varshochian R, Riazi-Esfahani M, Jeddi-Tehrani M, Mahmoudi AR, Aghazadeh S, Mahbod M, Movassat M, Atyabi F, Sabzevari A, Dinarvand R (2015) Albuminated PLGA nanoparticles containing bevacizumab intended for ocular neovascularization treatment. J Biomed Mater Res A 103:3148-3156

191. LuY, Zhou N, Huang X, Cheng JW, Li FQ, Wei RL, Cai JP (2014) Effect of intravitreal injection of bevacizumab-chitosan nanoparticles on retina of diabetic rats. Int J Ophthalmol 7:1-7

192. Yandrapu SK, Upadhyay AK, Petrash JM, Kompella UB (2013) Nanoparticles in porous microparticles prepared by supercritical infusion and pressure quench technology for sustained delivery of bevacizumab. Mol Pharm 10:4676-4686

193. Mu H, Wang Y, Chu Y, Jiang Y, Hua H, Chu L, Wang K, Wang A, Liu W, Li Y, Fu F, Sun K (2018) Multivesicular liposomes for sustained release of bevacizumab in treating laser-induced choroidal neovascularization. Drug Deliv 25:1372-1383

194. Abrishami M, Zarei-Ghanavati S, Soroush D, Rouhbakhsh M, Jaafari MR Malaekeh-Nikouei B (2009) Preparation, characterization, and in vivo evaluation of nanoliposomes-encapsulated bevacizumab (avastin) for intravitreal administration. Retina 29:699-703

195. OTX-IVT (Intravitreal depot technology for retinal drug delivery) (2019) Ocular Therapeutix. https://www.ocutx.com/research/otx-ivt/\#: :text= Ocular\%20Therapeutix\%20is\%20currently\%20developing,drugs\% 20to\%20targeted\%20ocular\%20tissues. Accessed 11 Mar 2021

196. Xie B, Jin L, Luo Z, Yu J, Shi S, Zhang Z, Shen M, Chen H, Li X, Song Z (2015) An injectable thermosensitive polymeric hydrogel for sustained release of Avastin ${ }^{\circledR}$ to treat posterior segment disease. Int J Pharm 490:375-383

197. Yu Y, Lau LC, Lo AC, Chau Y (2015) Injectable Chemically Crosslinked Hydrogel for the Controlled Release of Bevacizumab in Vitreous: A 6-Month In Vivo Study. TransI Vis Sci Technol 4:5

198. Lovett ML, Wang X, Yucel T, York L, Keirstead M, Haggerty L, Kaplan DL (2015) Silk hydrogels for sustained ocular delivery of anti-vascular endothelial growth factor (anti-VEGF) therapeutics. Eur J Pharm Biopharm 95:271-278

199. Rauck BM, Friberg TR, Mendez MCA, Park D, Shah V, Bilonick RA, Wang Y (2014) Biocompatible reverse thermal gel sustains the release of intravitreal bevacizumab in vivo. Invest Ophthalmol Vis Sci 55:469-476

200. Park D, Shah V, Rauck BM, Friberg TR, Wang Y (2013) An anti-angiogenic reverse thermal gel as a drug-delivery system for age-related wet macular degeneration. Macromol Biosci 13:464-469

201. Osswald CR, Guthrie MJ, Avila A, Valio JA Jr, Mieler WF, Kang-Mieler J (2017) In vivo efficacy of an injectable microsphere-hydrogel ocular drug delivery system. Curr Eye Res 42:1293-1301
202. Drug Approvals and Databases (2020) United States Food and Drug Administration. https://www.fda.gov/drugs/development-approvalprocess-drugs/drug-approvals-and-databases. Accessed 13 Mar 2021

203. Campochiaro PA, Marcus DM, Awh CC, Regillo C, Adamis AP, Bantseev V, Chiang Y, Ehrlich JS, Erickson S, Hanley WD, Horvath J, Maass KF, Singh N, Tang F, Barteselli G (2019) The port delivery system with ranibizumab for neovascular age-related macular degeneration: results from the randomized phase 2 ladder clinical trial. Ophthalmology 126:1141-1154

204. Humayun M, Santos A, Altamirano JC, Ribeiro R, Gonzalez R, de la Rosa A, Shih J, Pang C, Jiang F, Calvillo P, Huculak J, Zimmerman J, Caffey $S$ (2014) Implantable micropump for drug delivery in patients with diabetic macular edema. TransI Vis Sci Technol 3:5

205. Shen HH, Chan EC, Lee JH, Bee YS, Lin TW, Dusting GJ, Liu GS (2015) Nanocarriers for treatment of ocular neovascularization in the back of the eye: new vehicles for ophthalmic drug delivery. Nanomedicine (Lond) 10:2093-2107

206. Pooja D, Kadari A, Kulhari H, Sistla R (2018) Lipid-based nanomedicines: current clinical status and future perspectives. In: Grumezescu AM (ed) Lipid Nanocarriers for Drug Targeting, William Andrew Publishing

207. Grumezescu AM (ed) (2018) Design of nanostructures for versatile therapeutic applications. William Andrew Publishing

208. Khiev D, Mohamed ZA, Vichare R, Paulson R, Bhatia S, Mohapatra S, Lobo GP, Valapala M, Kerur N, Passaglia CL, Mohapatra SS (2021) Emerging nano-formulations and nanomedicines applications for ocular drug delivery. Nanomaterials 11:173

209. Jeevanandam J, Chan YS, Danquah MK (2016) Nano-formulations of drugs: recent developments, impact and challenges. Biochimie 128-129:99-112

210. Barenholz Y, Amselem S, Goren D, Cohen R, Gelvan D, Samuni A, Golden EB, Gabizon A (1993) Stability of liposomal doxorubicin formulations: problems and prospects. Med Res Rev 13:449-491

211. BarenholzY (2012) Doxil ${ }^{\circledR}$-the first FDA-approved nano-drug: lessons learned. J Control Release 160:117-134

212. BarenholzY (2007) Amphipathic weak base loading into preformed liposomes having a transmembrane ammonium ion gradient: From the bench to approved DOXIL. In: Gregory G (ed) Liposome Technology, 3rd edn, CRC Press

213. Gabizon AA, Barenholz Y (2010) Method for drug loading in liposomes. US Patent 12/802,545, 30 Sep 2010

214. Perry JL, Herlihy KP, Napier ME, Desimone JM (2011) PRINT: a novel platform toward shape and size specific nanoparticle theranostics. Acc Chem Res 44:990-998

215. Acharya G, Shin CS, McDermott M, Mishra H, Park H, Kwon IC, Park K (2010) The hydrogel template method for fabrication of homogeneous nano/microparticles. J Control Release 141:314-319

\section{Publisher's Note}

Springer Nature remains neutral with regard to jurisdictional claims in published maps and institutional affiliations.

\section{Submit your manuscript to a SpringerOpen ${ }^{\circ}$ journal and benefit from:}

- Convenient online submission

- Rigorous peer review

- Open access: articles freely available online

- High visibility within the field

- Retaining the copyright to your article

Submit your next manuscript at $\boldsymbol{\nabla}$ springeropen.com 